Dariusz Jarosz

Warszawa

\title{
Władza a książka społeczno-polityczna w PRL 1956-1989*
}

W dotychczasowych opracowaniach naukowych na temat politycznych uwikłań wydawania i dystrybucji książek w Polsce cezurą rzadko przekraczaną przez badaczy jest rok 1956. Dzięki nim wiemy dość dużo o stosunku ówczesnych władz do spraw książki, o przemianach bibliotek, księgarstwa i ruchu wydawniczego. Opisano również proces uzależniania „czytelnictwa masowego" od centralnego planisty. Tym celom służyło utworzenie 7 maja 1948 r. Komitetu Upowszechniania Książki (KUK). Jego zadaniem miało być m.in. opracowanie planu wydawniczego na lata 1948-1949 oraz koordynowanie wydawania masowych i tanich książek. Odpowiednie ich listy zostały opracowane już w 1948 roku$^{1}$. Odtąd państwo, doskonaląc odpowiednie instrumenty instytucjonalne, nie tylko decydowało, kto wydaje i drukuje książki, lecz także wzięło na siebie ciężar decydowania o tym, co winni czytać obywatele Polski Ludowej. Produkcja książek - tak jak inne działy gospodarki - została poddana drobiazgowemu planowaniu. Jego szczegóły wypracowywała powstała 29 lipca 1949 r. Centralna Komisja Wydawnicza przy Prezydium Rady Ministrów, a od 1951 r. wspomniany już Centralny Urząd Wydawnictw, Przemysłu Graficznego i Księgarstwa przy Prezydium Rady Ministrów. Urzędowi temu podporządkowano wszystkie instytucje wydawnicze poza niektórymi tzw. resortowymi, ale i te ostatnie były uzależnione od niego w zakresie przydziału papieru, drukarń i dystrybucji książek. Nad koncepcjami ideologicznymi planu wydawniczego pracowało stalinowskie superministerstwo - Państwowa Komisja Planowania Gospodarczego (PKPG). To tam przesądzano o tym, jakie będą priorytety produkcji wy-

* Artykuł ten jest znacznie rozszerzoną wersją referatu wygłoszonego 28 marca 2014 roku na konferencji naukowej $\mathrm{J}=$ „Na co dzień i od święta. Książka w życiu Polaków w XIX-XXI wieku”, zorganizowanej przez Instytut Informacji Naukowej i Studiów Bibliologicznych Uniwersytetu Warszawskiego.

${ }^{1}$ S. Kondek, Władza i wydawcy. Polityczne uwarunkowania produkcji ksiażek w Polsce w latach 1944-1949, Warszawa 1993, s. 178-202. 
dawniczej. Wśród nich największe znaczenie przywiązywano do książek i broszur na temat planu sześcioletniego lat 1950-1955, thumaczeń z języka rosyjskiego i dzieł klasyków marksizmu oraz polskiego i radzieckiego socrealizmu².

Centralizacja ruchu wydawniczego i poddanie go mechanizmom ideologicznie motywowanego planowania powodowały, że oferta wydawnicza, mimo, że imponująca ilościowo (w 1949 r. opublikowano 4602 tytuły książek o nakładzie 72905 tys. egz.; w 1950 - 4611 o nakładzie 118860 tys. egz. ${ }^{3}$ ) coraz bardziej rozmijała się z gustami czytelniczymi. W efekcie rosły remanenty ówczesnego monopolisty w zakresie księgarstwa - „Domu Książki”. O ile wartość niesprzedanej produkcji z lat 1945-1949 szacowano na 127818 tys. zł (27 054 tys. egzemplarzy), to w 1950 odpowiednio 133024 tys. zł (28 141 tys. egz.), w 1951 -227461 tys. zł (39 844 tys. egz. $)^{4}$.

Wiedza o tym, jak ,,wielka polityka” kształtowała stosunek władz PRL do książki w okresie postalinowskim jest mniej systematyczna i bardziej wyrywkowa. Jednym z ważnych elementów tej polityki był sposób traktowania tzw. literatury społeczno-politycznej.

\section{Gomułkowskie ,porządkowanie” polityki wydawniczej}

Główny zrąb przedstawionych ustaleń na ten temat oraz uwag dotyczących szerszego kontekstu politycznych uwikłań produkcji i upowszechniania książek, pochodzi zarówno z opracowań, w większości wykorzystujących nowe możliwości badawcze, stworzone przez otwarcie archiwów podstawowych instytucji państwowych i partyjnych po 1989 r., jak również jest efektem szczegółowej kwerendy archiwalnej dokumentów zgromadzonych w zespole Komitetu Centralnego Polskiej Zjednoczonej Partii Robotniczej (KC PZPR) w Archiwum Akt Nowych, głównie w jego wydziałach zajmujących się kultura, propagandą i agitacją oraz ideologią. Jako źródło pomocnicze wykorzystano prasę fachową (wydawniczo-księgarska).

Odnalezione dokumenty dowodzą, że decyzje w sprawie tego, jakie książki należy wydawać i promować zaczęto wypracowywać już w końcu lat pięćdziesiątych. Była to reakcja na diagnozę sytuacji zastanej

${ }^{2}$ D. Jarosz, Dzieje ksiażki w Polsce 1944-1989. Wybór źródet, Warszawa 2010, s. 19.

${ }^{3}$ W. Stankiewicz, S. Siekierski, Kształtowanie sie polityki wydawniczej w minionym trzydziestoleciu, „Rocznik Biblioteki Narodowej”, 10:1974, s. 82; K. Bańkowska - Bober, Statystyka wydawnictw w Polsce. Historia, metodyka i organizacja, Warszawa 2006, s. 92-94, tabl. 1.

4 S. A. Kondek, Papierowa rewolucja. Oficjalny obieg ksiażek $w$ Polsce $w$ latach 1948-1955, Warszawa 1999, s. 64. 
w ruchu wydawniczym tuż po objęciu władzy przez nową ekipę. Sądzę, że należy ja postrzegać w szerszym kontekście narastającego konfliktu z środowiskami ludzi kultury i nauki. Po likwidacji stojącego w awangardzie przemian października 1956 r. tygodnika „Po prostu” (październik 1957) nowy przywódca partii postanowił rozprawić się z rewizjonistami. Etapami tej rozgrywki były IX i X posiedzenia plenarne KC PZPR (1518 maja 1957 r. i 24-26 października 1957 r.), a uwieńczeniem III zjazd partii (10-19 marca 1959). Nowy kurs oznaczał nie tylko „dyscyplinowanie" środowisk twórczych i naukowych. Ustabilizowane kierownictwo partyjne postanowiło również ,uporządkować” politykę wydawniczą.

Tak jak w okresie stalinizmu, odpowiedź władzy na pytanie: „co przede wszystkim winni czytać Polacy?” brzmiała: literaturę społeczno-polityczną ${ }^{5}$. Określenie to pojawia się w całym analizowanym okresie, aż do końca PRL. Co oznaczało? Odpowiedzi na to pytanie należy poszukiwać $\mathrm{w}$ aktach instytucji, które nim się posługiwały. W analizowanych materiałach źródłowych pozostawiające wiele do życzenia próby sprecyzowania tego pojęcia pojawiają się rzadko i stosunkowo późno. W 1985 r. dokonał tego zastępca kierownika Wydziału Kultury KC Kazimierz Molek: „Pojęciem «książka społeczno-polityczna», szerokim i nieostrym [sic!] obejmujemy bardzo bogaty wachlarz publikacji, od literatury pięknej począwszy, poprzez prace publicystyczne, popularnonaukowe, reportażowe, aż do książek stricte naukowych, dla których wspólnym mianownikiem jest traktowanie o problemach ważnych dla życia społecznego, politycznego, gospodarczego itd. Słowem - to literatura nieobojętna, traktująca o współczesności lub pisana z pozycji współczesnych, ważka i niezbędna w procesie bezpośredniego oddziaływania na wiedzę i świadomość jednostek i grup społecznych. Przeciwnicy socjalizmu i niektórzy kontestatorzy próbowali mianu «literatura społeczno-polityczna» nadać sens pejoratywny, sugerując, że ta kategoria obejmuje duże ilości publikacji w «czerwonych okładkach», zalegających półki, nie czytanych, książekcegieł i broszur służących wyłącznie komunistycznej propagandzie i agitacji”. Jeszcze mniej precyzyjną definicję przedstawił Stanisław Kryśkow na łamach „Przeglądu Księgarskiego i Wydawniczego” w 1986. Jego zdaniem sa to ,wszystkie wydawnictwa mające wpływ na kształtowanie pożądanych cech osobowości, książki, które kształtują poglądy, postawy,

${ }^{5} \mathrm{O}$ trudnościach upowszechniania tej literatury zaczęto pisać w sposób bardziej otwarty w prasie branżowej w 1956 r. Zob. Z. S., W sprawie literatury spoleczno-politycznej, „Głos Księgarza” 1956, nr 11.

${ }^{6}$ K. Molek, Przed XIX Dekada Ksiażki Społeczno-Politycznej ,,Człowiek - Świat Polityka”, „Przegląd Księgarski i Wydawniczy” 1985, nr 7-8. 
kształcą i wychowuja. Odpowiada mi pogląd, że literatura społeczno-polityczna jest piśmiennictwem typu popularnonaukowego. Podkreśliłbym jej internacjonalno-polityczny wydźwięk wychowawczy"7.

Jak widać do tej zbiorczej kategorii zaliczano książki różniące się gatunkowo. To co je łączyło, to bezpośrednia użyteczność dla kształtowania świadomości, postaw i zachowań społecznych uznanych za właściwe przez władze komunistyczne.

Nawet jeżeli ustalenie definicji literatury społeczno-politycznej natrafiało na problemy, to na podstawie dokumentów wytworzonych przez centralne gremia partyjne można ustalić, co przede wszystkim do niej zaliczano. Były to więc w pierwszej kolejności dzieła klasyków marksizmu-leninizmu, aktualnych przywódców partii komunistycznych oraz uznawane za marksistowskie naukowe i popularnonaukowe publikacje filozoficzne, przyrodnicze (szczególnie te, które koncentrowały się na problematyce powstawania świata, materii, budowy wszechświata, pochodzenia człowieka i cywilizacji), ekonomiczne, psychologiczne i socjologiczne. Wśród książek historycznych na listach literatury społeczno-politycznej znalazły się przede wszystkim publikacje dotyczące dziejów najnowszych Polski i świata, ze szczególnym uwzględnieniem studiów na temat Polski Ludowej oraz ruchu robotniczego i ludowego. Ważne znaczenie w kanonie tej literatury odgrywały prace poświęcone polityce wyznaniowej, religioznawcze i tzw. światopoglądowe, propagujące idee ateizmu i laicyzacji. Duża arbitralność cechowała selekcję zaliczanych do tej grupy dzieł beletrystycznych. Dominowały uznawane za politycznie poprawne literackie wizje przemian dokonanych w Polsce po 1944 r. oraz książki zawierające wywodzącą się z tradycji lewicowych (w tym również radykalnie lewicowych) interpretację przeszłości.

Bez względu na to jak zdefiniujemy zakres tej literatury, to nie ulega wątpliwości, że spuścizną stalinizmu była wzrastająca niechęć do niej. Zmiany polityczne spowodowały, że jej produkcja gwałtowanie zmalała. W prasie fachowej po 1956 r. można znaleźć informacje o tym, iż jeszcze w 1955 r. wydano 149 tytułów książek zaliczanych do tej literatury w nakładzie 3391 tys. egzemplarzy, w 1956 - odpowiednio: 125 tytułów i 1768 tys. egzemplarzy, a w 1957: 51 tytułów i 325 tys. egzemplarzy ${ }^{8}$.

O tym, że do tego typu książek zaczęto przywiązywać na nowo szczególną wagę w warszawskim centrum władzy już w końcu lat pięćdzie-

7 S. Kryśkow, Upowszechnienie książki społeczno-politycznej, „Przegląd Księgarski i Wydawniczy", 1986, nr 11.

${ }^{8}$ D. Musiałowa, Nowe tendencje, „Praca Księgarska”, 1962, nr 9. 
siątych, świadczy powołanie Komisji Literatury Społeczno-Politycznej przy Wydziale Propagandy i Agitacji KC PZPR. Jej pierwsze posiedzenie odbyło się 10 listopada 1959 r. ${ }^{9} \mathrm{~W}$ dokumencie, opracowanym w tym okresie przez Wydzial, dokonano charakterystycznej oceny wydawnictw społeczno-politycznych. Pisano m.in.: ,Jeśli sytuacja 1957 r. była nacechowana wzmożonym naporem literatury burżuazyjnej oraz rewizjonistycznej chaotycznością i przypadkowością naszej praktyki wydawniczej w tym zakresie, to lata 1958-1959 przynoszą wzmożenie ofensywy marksistowskiej i świadomie jej sprzyjającą politykę wydawniczą". „Marksistowskie środowisko naukowe dopiero teraz [tzn. w 1959 roku - DJ] zaczyna ujawniać pozytywne skutki zmian wprowadzonych do naszej polityki kulturalnej, dopiero teraz bowiem ukazują się prace podjęte w nowym klimacie naukowym". Tendencję tę należy podtrzymać stawiając odpowiednie zadania przed wydawnictwami. Konstatowano brak książek antymarksistowskich z takiej dyscypliny jak ekonomia polityczna, ale można je odnaleźć w dziedzinie filozofii, socjologii, psychologii, w mniejszym stopniu w pedagogice. Wśród prac otwarcie niemarksistowskich wymieniano książki autorów katolickich (Mieczysława Krąpca OP, ks. Józefa Pastuszki), Tadeusza Czeżowskiego, Wiktora Wąsika (Historia filozofii polskiej, t. 1), Józefa Chałasińskiego (Przeszłość i przyszłość inteligencji polskiej), Stanisława Ossowskiego (Struktura klasowa w społecznej świadomości). W latach 1957-1959 wznowiono - zdaniem autorów dokumentu - nadmiernie wiele prac niemarksistowskich zalewając nimi rynek (Historia filozofii Władysława Tatarkiewicza wyszła w łącznym nakładzie 22,5 tys. egzemplarzy).

Szczególnie silny „nacisk obcej ideologii” miał nastapić w dziedzinie przekładów: „Zarzucono właściwie zupełnie w 1956-57 przekłady autorów radzieckich i innych prac marksistowskich". Obawy budziło operowanie nakładami: średni nakład prac marksistowskich to 3 tys. egz., a niemarksistowskich -5 tys. W naukach filozoficznych ilość pozycji marksistowskich i ,sojuszniczych" [sic!] zwiększyła się z $40 \mathrm{w} 1958$ r. do 42 w 1959 r., w tym czasie łączna liczba „,pozycji burżuazyjnych”, ,katolickich itp." wynosiła odpowiednio 19 i 26. Najgorszą sytuację pod tym względem zanotowano w psychologii: w latach 1958-1959 ukazało się 10 prac marksistowskich i 10 ,sojuszniczych”, prac „burżuazyjnych” zaś wydano w tym okresie 20. Jako osiagnięcia w dziedzinie filozofii marksistowskiej traktowano książki: Adama Schaffa (wznowienie pracy o fi-

9 AAN, Komitet Centralny Polskiej Zjednoczonej Partii Robotniczej (dalej: KC PZPR), 237/VIII-466, F. Chaber, Komisja Literatury Społeczno-Politycznej, Protokół I posiedzenia Komisji 10 XI 1959, k. 44. 
lozofii prawdy), Bohdana Suchodolskiego (o historii filozofii), Janusza Kuczyńskiego (prawdopodobnie chodzi o pracę ateistyczną „Urok wiary”), Karola Martela, przekłady Grigorija Deborina, Jerzego Plechanowa i Karla Kautsky'ego. W 1959 z zakresu socjologii ukazały się pierwsze marksistowskie prace Józefa Wiatra, Zygmunta Baumana, Jerzego Szackiego i Andrzeja Walickiego. Z pozytywnymi opiniami Wydziału Propagandy i Agitacji KC spotkały się tomy studiów nad klasą robotniczą i inteligencja pod redakcją Jana Szczepańskiego, oraz prace prawników: Sylwestra Zawadzkiego, Stanisława Ehrlicha, Bogusława Leśnodorskiego i Andrzeja Gwiżdża. W konkluzji tego dokumentu pisano: „Z powyższych uwag nasuwa się wniosek następujący: w rywalizacji naukowejmimo niekorzystnych warunków startu w 1957 r. - uczeni marksistowscy zdobywają obecnie przewagę"10.

Ta optymistyczna ocena pojawia się również $\mathrm{w}$ innych dokumentach Komitetu Centralnego partii z początków lat sześćdziesiątych. W „Uwagach o literaturze społeczno-politycznej”, sformułowanych w październiku 1963 r. przez Wydział Propagandy i Agitacji stwierdzono, że od III Zjazdu PZPR zaznacza się postęp w rozwoju popularnej literatury społeczno-politycznej. Zaniechano wydawania książek szablonowych, „nie trafiających do przekonania czytelnika”. Zaczyna się kształtować nowy typ książki politycznej „wychodzącej od rzeczywistości, wyjaśniającej ją po marksistowsku, mobilizującej do aktywnego wcielania w życie linii partii”. Jako udane próby nowych form i serii wydawniczych uznano „100 pytań i odpowiedzi” i wielotomową serię „Rozmowy o gospodarce". Wyliczono, że w tym czasie ukazywało się 14 stałych popularnych serii wydawniczych zajmujących się problematyką społeczno-polityczną. Największą rolę przypisywano wydawnictwom o polityce ekonomicznej partii i gospodarce Polski (prace zbiorowe do szkolenia partyjnego: „Polityka gospodarcza Polski Ludowej” i „Ekonomika rolnictwa i polityka rolna"). Co prawda, niedostatecznie jeszcze miała być eksponowana problematyka współzawodnictwa socjalizmu z kapitalizmem, ale z drugiej strony osiagnięto postęp w literaturze dotyczącej filozofii marksistowskiej oraz socjalistycznej etyki i obyczajowości. „Posiadamy obecnie kilka wartościowych prac poświęconych krytyce mieszczańskiego stylu życia, groszoróbstwa, bezideowości i postaw sprzecznych z moralnością socjalistyczną (np. prace H[enryka] Jankowskiego). Na ogół pomyślnie rozwija się literatura antyfideistyczna i antyklerykalna [...]. Większą uwagę trzeba jednak zwrócić na problematykę aktualną, dotycząca

${ }^{10}$ AAN, KC PZPR, 237/VIII-466, Wydział Propagandy i Agitacji KC PZPR, Uwagi krytyczne o wydawnictwach społeczno-politycznych [1959], k. 108-118. 
zwłaszcza działalności kościoła w Polsce Ludowej oraz polityki wyznaniowej naszego państwa"l1.

W dziedzinie badań nad dziejami Polski i ruchu rewolucyjnego jako na ważny dorobek naukowy wskazano postępy prac nad Historia Polski autorstwa badaczy z Instytutu Historii PAN, na książki Henryka Jabłońskiego, Józefa Kowalskiego, Witolda Kuli, Jerzego Tomaszewskiego $\mathrm{i}$ innych. Jako braki w tej dziedzinie wytykano: ,niedostatek marksistowskiej popularyzacji, przy bardzo atrakcyjnych opracowaniach niemarksistowskich, dysproporcję między dużą ilością prac faktograficznych wycinkowych a niedostatkiem prac syntetycznych, zbyt słabe oświetlenie najnowszych dziejów Polski i historii powszechnej".

Tematyka międzynarodowa miała być rozwijana zarówno w pracach naukowych jak i popularnych. Szczególnie dotyczyło to walk narodowowyzwoleńczych, neokolonializmu, tendencji rozwojowych państw tzw. trzeciego świata i cennych publikacji z zakresu literatury niemcoznawczej. Rosło - zdaniem autorów dokumentu - zainteresowanie książką rosyjską $i$ to nawet tą oryginalną.

Wreszcie na koniec tych „Uwag” wspomniano, że istnieje zamiar dorocznego ustalenia przez wydziały KC i Ministerstwo Kultury zestawu 100 najcenniejszych „godnych upowszechnienia” książek, które muszą być wznawiane i szeroko reklamowane w prasie, radio, telewizji i efektywnie rozpowszechniane ${ }^{12}$.

Ta konstatacja dobitnie wskazuje, że zamiarem władz partyjnych było nie tylko inspirowanie powstawania i wydawania prac o charakterze społeczno-politycznym, ale również podjęcie wysiłku ich upowszechniania. I choć nie udało się natrafić na ślad wspomnianej listy 100 książek, to zamierzenia ich specjalnego upowszechniania podejmowano coraz częściej ${ }^{13}$.

${ }^{11}$ AAN, KC PZPR, 237/VIII-467, KC PZPR Wydział Propagandy i Agitacji, Uwagi o literaturze społeczno-politycznej, 24 X 1963, k. 7-9.

${ }^{12}$ Tamże, k. 7-9.

${ }^{13}$ W 1962 r. Danuta Musiałowa w artykule Nowe tendencje w tygodniku „Praca Księgarska" (nr 9) pisała, że upowszechnianie książki społeczno-politycznej zaczęło przynosić dobre efekty dzięki zwiększonym dostawom nowości i skutecznym pociagnięciom organizacyjnym: „Umowa o zakup zawarta ze Spółdzielnią Wydawniczą «Książka i Wiedza», wprowadzenie obowiązku posiadania we wszystkich księgarniach określonego asortymentu książek społeczno-politycznych i światopoglądowych, wyodrębnienie z ogólnego asortymentu półek $\mathrm{z}$ tą literatura, próby wprowadzenia książki światopoglądowej do sklepów GS oraz do kiosków kolporterów zakładowych i ulicznych, specjalne szkolenie i przeglądy nowości politycznych organizowane przez przedsiębiorstwa $\mathrm{D}$ [omu]K[siążki] dla księgarzy, ciagłe występowanie księgarzy ze sprzedażą i wystawami odpowiednich książek przy różnego rodzaju uroczystościach i obchodach krajowych i lokalnych - to tylko główne z przedsięwzięć, zmierzających do przywrócenia odpowiedniego miejsca książce politycznej w księgarni i zdobycia dla niej należnej pozycji w społeczeństwie”. 
W rozumowaniu władz partyjnych dużą wagę przywiązywano do odpowiedniego sprofilowania prac o charakterze społeczno-politycznym tak, aby trafiały do różnych typów odbiorców.

Specjalną uwagę przywiązywano do wydawnictw masowych. Na początku lat sześćdziesiątych należały do nich przede wszystkim „Kalendarz Robotniczy”, „Magazyn Iskier” i „Kalendarz Kółek Rolniczych”. Ich zaletą z punktu widzenia władz partyjnych było docieranie do szerokich środowisk robotniczych i chłopskich, które często nie czytały innych wydawnictw społeczno-politycznych. Z tych przyczyn „Kalendarz Robotniczy" z 1963 r. uległ istotnym zmianom: zredukowano materiał historyczny i rocznicowy, skrócono zamieszczone w nim artykuły, wzbogacono go o problematykę gospodarcza, „współczesnego świata”, zamieszczono teksty popularyzatorskie o najważniejszych dziełach literatury politycznej i pięknej.

Z punktu widzenia celów tego typu wydawnictw przedmiotem krytyki stał się „Kalendarz Kółek Rolniczych” za brak popularyzacji kultury, informacji o życiu klasy robotniczej i o kwestii niemieckiej oraz ograniczenie się do wąskiej dziedziny zagadnień rolniczych ${ }^{14}$.

Oceniając literaturę społeczno-polityczną dla młodzieży wydaną w latach 1961-1962 za sukces uznano publikację książek w popularnych seriach ,z zakresu zagadnień ideologicznych” takich jak: „Co to jest” Wydawnictwa Iskry oraz „Fi” Książki i Wiedzy” (popularyzujące filozofię). Chwalono również „Bibliotekę Postępowego Wychowania” Iskier. W ramach tych serii szczególnie wyróżniano prace: Socjologia na co dzień Zygmunta Baumana, Naród i rasa w świadomości społecznej Jerzego Wiatra, Pożegnanie z katechizmem Jerzego Broszkiewicza, Od religii do filozofii Henryka Hinza, Wychowanie a religia Bertranda Russela, Mtodość w cieniu paragrafu Mikołaja Kozakiewicza, $O$ dowodach istnienia Boga Władysława Kozłowskiego ${ }^{15}$.

W „Uwagach o planie wydawnictw społeczno-politycznych na rok 1965” Ryszard Paciorkowski z Wydziału Propagandy i Agitacji KC PZPR wyliczał, że w kilku latach poprzednich stanowiły one około $1 / 3$ tytułów i arkuszy wydawniczych oraz egzemplarzy książek wydanych w Polsce. Wadą tej produkcji miała być zbyt duża liczba tytułów przy stosunkowo niskich nakładach. Tylko jedno wydawnictwo - wspomniany „Kalendarz Robotniczy" - osiagał nakład 80 tys. egzemplarzy; nakład pozostałych

${ }^{14}$ AAN, KC PZPR237/VIII-468, O literaturze na temat problemów społeczno-politycznych kraju, k. 64-65.

15 Tamże, Ocena literatury społeczno-politycznej dla młodzieży. Realizacja w latach 1961 i 1962 i plan na 1963, k. 43-48. 
publikacji tej grupy, poza nielicznymi wyjątkami, kształtował się w granicach 5-20 tys. Postulował więc większą koncentrację wydawców na tytułach masowych, szczególnie wartościowych z punktu widzenia ideowo-politycznego i zapewnienie tego rodzaju książkom wysokich nakładów. W planie wydawniczym na 1965 r. za wyjątkowo cenne uznano publikacje „literatury laickiej”: wznowienie Opowieści biblijnych Zenona Kosidowskiego oraz antyklerykalnych reportaży Jerzego Ambroziewicza i Aleksandra Rowińskiego. Dla pokazania ,antyhumanistycznej istoty obskurantyzmu i fanatyzmu religijnego" należało - zdaniem Paciorkowskiego - zwiększyć liczbę publikacji w rodzaju reportaży Andrzeja K. Wróblewskiego oraz Zbigniewa Stolarka (Bytem w Lourdes: miasto cudów widziane własnymi i cudzymi oczami $)^{16}$.

Mimo tych sukcesów, pojawienia się nowych serii i wysiłków wydawniczych, stan czytelnictwa i dostępności tej literatury nie był oceniany jako zadowalający. Jej przeciętny nakład w tym okresie wahał się w granicach 11-13 tys. egzemplarzy, choć przemówienia Gomułki publikowano w 20-100 tys. egzemplarzy, a „120 pytań i odpowiedzi” - w rekordowym nakładzie 110 tys. egz.

Porównanie tychże nakładów i rezultatów upowszechnienia książki społeczno-politycznej z liczebnością aktywu partyjnego i społecznego, z liczbą wykładowców i uczestników różnych form szkolenia ideologicznego, studentów oraz nauczycieli wykładających przedmioty ideologiczne, z liczebnością kierowniczej kadry państwowej, gospodarczej itp. wskazywał, że poziom czytelnictwa literatury społeczno-politycznej mimo pewnej poprawy był nadal niezbyt wysoki. Szacowano wówczas, że w systemie szkolenia ideologicznego kształciło się 45 tys. zespołów z ok. 1,5 mln uczestników. Wieczorowe Szkoły Aktywu Związku Młodzieży Socjalistycznej obejmowały ponad 100 tys. osób, a podstawy nauk społecznych studiowało ok. 200 tys. osob. Tym wielkościom odpowiadała sprzedaż książek o nakładach 5-80 tys. egz. Ich wypożyczenia w bibliotekach (poza Ośrodkami Propagandy Partyjnej) - były minimalne. Dowodziło to, że nie czytali tej literatury nawet szkolący się członkowie partii. Udział wydawnictw społeczno-politycznych w zakupach w grupie wydawnictw popularno-naukowych przez biblioteki publiczne spadł z 20\% w 1955 r. do 1,1-10,2\% (średnia 4,4\%) w następnych la$\operatorname{tach}^{17}$.

${ }^{16}$ AAN, KC PZPR 237/VIII-927, R. Paciorkowski, Uwagi o planie wydawnictw społeczno-politycznych na 1965 rok, Warszawa 26 I 1965, k. 33-41.

${ }^{17}$ AAN, KC PZPR, 237/VIII-929, Informacja W. Propagandy i Agitacji KC PZPR o niektórych problemach czytelnictwa wydawnictw społeczno-politycznych [1967], k. 24-27. 
Informacje docierające do warszawskiej centrali partii mówiły o tym, że słabość czytelnictwa tej literatury wynikała nie tylko (a może nie przede wszystkim) z jej małych nakładów i niedostatecznych zakupów przez biblioteki. Wydział Propagandy KW PZPR we Wrocławiu raportował, że czytająca publiczność poszukiwała innego typu książek. Tamtejsi bibliotekarze mówili o „barierze światopoglądowej”, zniechęcającej do tego typu literatury jako ,propagującej laicyzm”. Z wyrywkowej i niepełnej analizy stanu zaopatrzenia i sprzedaży wydawnictw społeczno-politycznych dokonanej w dolnośląskich księgarniach wynikało, że najwięcej książek sprzedano z działu: państwo i prawo, a najmniej z działów: marksizm-leninizm oraz ZSRR i kraje demokracji ludowej ${ }^{18}$.

Sondowanie sytuacji panującej na Dolnym Śląsku było elementem szerszych działań Wydziału Propagandy i Agitacji KC PZPR, mających na celu zorientowanie się w stanie czytelnictwa literatury społeczno-politycznej. Podobne oceny zostały w pierwszym półroczu 1967 r. dokonane przez wszystkie Komitety Wojewódzkie partii. Miały one wykazać, że co prawda ,,istnieje na rynku księgarskim różnorodna tematycznie i dostosowana do zainteresowań różnych grup odbiorców literatura społeczno-polityczna. Stopień jej czytelnictwa jest jednak - mimo obserwowanej w ostatnich latach poprawy - nadal niezadowalający. Składa się na to szereg przyczyn, m.in.: brak nawyku systematycznego korzystania z książki przez aktyw partyjny i społeczny, niedostatek informacji o ważnych publikacjach w prasie, radio i telewizji, słabe zaangażowanie organizacji politycznych i społecznych $\mathrm{w}$ działalności na rzecz popularyzacji tej literatury, niedomagania w pracy bibliotek i księgarstwa"19. Nieprzypadkowo te oceny zbiegły się z uchwałami VIII plenum KC PZPR (16-17 maja 1967 r.), nakazującymi pogłębienie pracy ideowo-wychowawczej" tak w partii, jak i w całym społeczeństwie ${ }^{20}$.

W poszukiwaniu nowej formy upowszechniania: Dni Książki Społeczno-Politycznej „Człowiek - Świat - Polityka”

Wskazane przyczyny sprawiły, że postanowiono w dniach 20-30 listopada 1967 r. zorganizować po raz pierwszy w skali całego kraju Dni

\footnotetext{
${ }^{18}$ AAN, KC PZPR, 237/VIII-929, Informacja o zaopatrzeniu i czytelnictwie literatury społeczno-politycznej na Dolnym Śląsku, Wydział Propagandy KW PZPR we Wrocławiu, Wrocław, czerwiec 1967, k. 32.

${ }^{19}$ AAN, KC PZPR, 237/VIII-928 Wydział Propagandy i Agitacji KC PZPR do sekretarza KC W. Jarosińskiego w sprawie czytelnictwa i popularyzacji literatury społeczno-politycznej, 20 września 1967.

${ }^{20}$ Człowiek - Świat - Polityka. Rozmowa z kierownikiem Wydzialu Propagandy i Agitacji KC PZPR tow. Tadeuszem Wrębiakiem. Rozmawiał Ludwik Krasucki, „Przegląd Księgarski i Wydawniczy”, 1969, nr 20.
} 
Książki Społeczno-Politycznej pod nazwą „Człowiek - Świat - Polityka” $(\mathrm{DKS}-\mathrm{P})^{21}$. Cykl corocznych imprez, który czasami zamiennie nazywano Dekadą Książki Społeczno-Politycznej „Człowiek - Świat - Polityka”, odbywał się zwykle w ostatniej dekadzie listopada pod auspicjami KC PZPR i przetrwał do końca PRL-u.

Tak jak w przypadku starszych, mających miejsce w maju każdego roku Dni Oświaty, Książki i Prasy (DOKiP) już wkrótce DKS-P przybrały mocno zrytualizowany kształt. Składały się na nie spotkania z autorami, wieczory dyskusyjne, konkursy czytelnicze, wystawy książek społeczno-politycznych w księgarniach i bibliotekach, kiermasze, różne formy kolportażu w zakładach pracy i na wsi. Rozpoczynały się zwykle centralną inauguracja w Warszawie lub jednym z miast wojewódzkich. W centralnym Komitecie Organizacyjnym zasiadali wysocy ranga przedstawiciele ministerstw: Kultury i Sztuki oraz Oświaty, wydziałów: Kultury oraz Propagandy i Agitacji KC PZPR, organizacji młodzieżowych, Zjednoczonego Stronnictwa Ludowego i Stronnictwa Demokratycznego, Domu Książki, Stowarzyszenia Bibliotekarzy Polskich, Biblioteki Narodowej22.

Tak jak w przypadku DOKiP, kolejne edycje Dekady, oprócz celów generalnych, realizowały aktualne zapotrzebowania ideowo-propagandowe władz partyjnych, wynikające z obchodów ważnych dla nich rocznic lub aktualnych wydarzeń politycznych. Ich niekompletny wykaz zawiera tabela 1 .

${ }^{21}$ AAN, KC PZPR, 237/VIII-928 Wydział Propagandy i Agitacji KC PZPR do sekretarza KC W. Jarosińskiego w sprawie czytelnictwa i popularyzacji literatury społeczno-politycznej, 20 września 1967. W „Przeglądzie Księgarskim i Wydawniczym” z 1978 Zeznon Skuza twierdził, że inicjatywa Dni wyszła od księgarzy (Ekspansja ksiażki społeczno-politycznej, „Przegląd Księgarski i Wydawniczy”, 1978, nr 1). Szczegółowa kwerenda prasy księgarskiej wykazała, że 6 października 1958 r. w Łodzi i województwie łódzkim rozpoczęła się impreza nazwana „Tydzień książki społeczno-politycznej” (zob. J. Migdalski, , Tydzień ksiażki społeczno-politycznej” w woj. łódzkim, „Praca Księgarska”, 1958, nr 41). W 1960 r. „Dni Książki Społeczno-Politycznej” odbyły się w Katowicach (J. Migdalski, „,Dni Ksiażki Spoleczno-Politycznej” w Katowicach (Poradnik Reklamowy, dodatek do „Pracy Księgarskiej”, 1960, nr 37). Środowisko księgarskie było inicjatorem Klubu Ksiaż̇i „Człowiek - Świat - Polityka” (zob. K. Olejniczak, Nowy Klub Ksiażki: „Człowiek - Świat - Polityka”, „Przegląd Księgarski i Wydawniczy”, 1968, nr 7).

${ }^{22}$ W składzie Komitetu Organizacyjnego Dni w 1968 znaleźli się m.in.: Kazimierz Rusinek - wiceminister kultury i sztuki; Aleksander Syczewski, zastępca kierownika Wydziału Kultury KC; Stanisław Kosicki, zastępca kierownika Wydziału Propagandy i Agitacji KC, Włodzimierz Michajłow - wiceminister oświaty i szkolnictwa wyższego, Jadwiga Kołodziejska - sekretarz generalny Stowarzyszenia Bibliotekarzy Polskich, Witold Stankiewicz - dyrektor Biblioteki Narodowej. Zob. AAN, KC PZPR, 237/VIII1102, Ramowy program Dni Książki „Człowiek - Świat - Polityka” 20-30 XI 1968, Warszawa, grudzień 1968, k. 18-19. 
Tabela 1. Rocznice i znaczące wydarzenia polityczne, którym podporządkowano obchody Dekady Książki Społeczno-Politycznej „Człowiek - Świat - Polityka" w wybranych latach

\begin{tabular}{|c|l|}
\hline Rok & \multicolumn{1}{|c|}{ Rocznice i wydarzenia znaczące } \\
\hline 1967 & 50 rocznica rewolucji październikowej \\
\hline 1968 & $\begin{array}{l}\text { V Zjazd PZPR; 50-lecie powstania Komunistycznej Partii Robotniczej } \\
\text { Polski; 50-lecie odzyskania niepodległości; 20-lecie powstania PZPR. }\end{array}$ \\
\hline 1977 & 60 rocznica rewolucji październikowej \\
\hline 1978 & $\begin{array}{l}\text { 60 rocznica odzyskania niepodległości; 60 rocznica powstania } \\
\text { Komunistycznej Partii Robotniczej Polski; 30 rocznica zjednoczenia } \\
\text { ruchu robotniczego; 35 rocznica bitwy I Dywizji im. T. Kościuszki pod } \\
\text { Lenino; przygotowania do obchodów 35-lecia Polski Ludowej. }\end{array}$ \\
\hline 1979 & $\begin{array}{l}\text { VIII Zjazd PZPR; 35-lecie Polski Ludowej; 40-lecia napaści Niemiec } \\
\text { hitlerowskich na Polskę. }\end{array}$ \\
\hline 1982 & 100-lecie polskiego ruchu robotniczego; 60 rocznica utworzenia ZSRR. \\
\hline 1983 & $\begin{array}{l}\text { Popularyzacja treści XIII plenum KC PZPR; 100 rocznica śmierci } \\
\text { Karola Marksa. }\end{array}$ \\
\hline 1984 & 40-lecie Polski Ludowej \\
\hline 1985 & $\begin{array}{l}\text { 40-lecie zwycięstwa nad faszyzmem, 40 -lecie powrotu Ziem } \\
\text { Zachodnich i Północnych do Macierzy; 30-lecie podpisania Układu } \\
\text { Warszawskiego, 80-lecie rewolucji 1905 r. }\end{array}$ \\
\hline 1986 & $\begin{array}{l}\text { Dyskusja nad dorobkiem X Zjazdu PZPR i XXVII Zjazdu KPZR; Rok } \\
\text { Pokoju ogłoszony przez ONZ. }\end{array}$ \\
\hline 1987 & 70-lecie rewolucji październikowej; 65 rocznica powstania ZSRR \\
\hline 1988 & $\begin{array}{l}\text { 70 rocznica odzyskania niepodległości; 40 rocznica zjednoczenia } \\
\text { polskiego ruchu robotniczego i powstania PZPR; 45 rocznica } \\
\text { powstania Ludowego Wojska Polskiego }\end{array}$ \\
\hline
\end{tabular}

Źródło: AAN, KC PZPR, 237/VIII-1102, Wydział Propagandy i Agitacji oraz Wydział Kultury KC PZPR do sekretarzy KC Witolda Jarosińskiego i Artura Starewicza. Warszawa 18 VII 1968, k. 4-5.; tamże, Ramowy program Dni Książki „Człowiek - Świat - Polityka” 20-30 XI 1968, Warszawa, grudzień 1968, k. 18; AAN, KC PZPR W. Kultury LVI-717, Wytyczne na XI Dni Książki Społeczno-Politycznej „Człowiek - Świat - Polityka” 21-30 listopada 1977, k. nlb.; AAN, KC PZPR, Wydział Kultury LVI-1790; Wytyczne na XIII Dni Książki Społeczno-Politycznej „Człowiek - Świat - Polityka” 20-30 listopada 1979, Warszawa 31 sierpnia 1979, k. nlb.; AAN, KC PZPR. Wydział Kultury LVI-1791, Dni Książki „Człowiek - Świat - Polityka”[1983], k. nlb.; tamże, Kierownik Wydziału Kultury KC Witold Nawrocki, Kierownik Wydziału Ideologicznego Władysław Loranc Kierownik Wydziału Prasy, Radia i TV Bogdan Jachacz do sekretarzy KW, Warszawa 3 XI 1983, k. nlb.; AAN. KC PZPR Wydział Kultury LVI-1494, Wytyczne na XVII Dni Książki Społeczno-Politycznej „Człowiek - Świat - Polityka”, Warszawa, październik 1983, k. nlb.; AAN, KC PZPR Wydział Kultury LVI-1792, Wytyczne na XVIII Dni Książki „Człowiek - Świat - Polityka”, Rada ds. Książki Społeczno-Politycznej przy KC PZPR, Warszawa, lipiec 1984, k. nlb.; AAN, KC PZPR, LVI-1793, Założenia programowe i organizacyjne XIX Dni Książki SpołecznoPolitycznej „Człowiek - Świat - Polityka”, Warszawa lipiec 1985, k. nlb.; AAN, KC PZPR, LVI-1798, Założenia programowe i organizacyjne XX Dni Książki Społeczno-Politycznej „Człowiek - Świat - Polityka”, Warszawa lipiec 1986, k. nlb.; ibidem, Założenia programo- 
we i organizacyjne XXI Dni Książki Społeczno-Politycznej „Człowiek - Świat - Polityka” 20-30 listopada 1987, k. nlb.; AAN, KC PZPR W. Kultury LVI-1453, XXII Dekada Książki Społeczno-Politycznej, październik 1988, k. nlb.

Nawet ten dalece niekompletny przegląd ,tematów przewodnich” Dni wskazuje na charakterystyczną powtarzalność dominującej problematyki i podporządkowaną założeniom ideologiczno-politycznym selekcję. Priorytetowo traktowano okragłe rocznice rewolucji październikowej, ważnych wydarzeń z dziejów polskiego i międzynarodowego ruchu politycznego, powstania Polski Ludowej i ZSRR, Ludowego Wojska Polskiego. Od 1968 r., w odstępach dziesięcioletnich, pojawiają się jako wydarzenia znaczące rocznice odzyskania niepodległości w 1918 r. Wreszcie DKS-P miały być okazją do wzmożenia zabiegów propagandowych wokół zjazdów partyjnych i niektórych posiedzeń plenarnych.

Zachowana sprawozdawczość zawiera podstawowe informacje dotyczące kwestii organizacyjnych Dni (harmonogram i liczba imprez, ich formy). Na tej podstawie można jedynie próbować wstępnie szacować skalę wysiłku podejmowanego dla ich przeprowadzenia. Dużo rzadziej i bardzo lakonicznie wspomina się w niej o reakcjach społecznych na owe imprezy.

W podsumowaniu pierwszej edycji DKS-P w 1967 r. stwierdzono, że odbyło się wtedy ponad 2 tys. spotkań czytelników z autorami i wydawcami książek politycznych, ponad 4000 wystaw, około 1500 kiermaszów literatury społeczno-politycznej, blisko 3 tys. odczytów i prelekcji zapoznających słuchaczy z dorobkiem edytorskim „w działach tematycznych marksistowskiego piśmiennictwa politycznego oraz z treścią najcenniejszych publikacji” oraz ponad 2 tys. przeglądów publikacji społeczno-politycznych i 4 tys. wystaw. Sprzedaż publikacji partyjnego wydawnictwa „Książka i Wiedza” osiagnęła w tym okresie wartość 4,2 mln zł, tj. 10\% całorocznej sprzedaży książek KiW. Szczególnie eksponowano dzieła klasyków marksizmu-leninizmu, pisma przywódców partii i rządu, propagujące postawy „,socjalistycznego patriotyzmu”, wkład Polskiej Partii Robotniczej (PPR) i PZPR do walki o niepodległość i wyzwolenie społeczne oraz związane z 50-leciem rewolucji październikowej ${ }^{23}$.

Informacje dotyczące drugiej edycji Dni w 1968 r. mówią o zorganizowaniu ponad 8,5 tys. wystaw, około 2,5 tys. spotkań z pisarzami, działaczami kulturalnymi oraz około 3 tys. odczytów ,powiązanych z aktual-

${ }^{23}$ AAN, KC PZPR, 237/VIII-1102, Wydział Propagandy i Agitacji oraz Wydział Kultury KC PZPR do sekretarzy KC Witolda Jarosińskiego i Artura Starewicza, Warszawa 18 VII 1968, k. 7. 
ną informacja polityczną". W ciagu 10 dni sprzedano książki o wartości $5,5 \mathrm{mln} \mathrm{zz}^{24}$.

Szczególnego rozmachu Dekada nabrała w latach siedemdziesiątych. Świadczy o tym chociażby zawartość odpowiedniego sprawozdania odnalezionego w aktach Wydziału Kultury KC PZPR, dotyczącego imprez z listopada 1978 roku.

W związku z obchodami 60-lecia odzyskania niepodległości odbyły się wówczas sesje naukowe i popularnonaukowe na ten temat w każdym województwie. Odbyły się również liczne konferencje i spotkania związane 60-leciem Komunistycznej Partii Polski (KPP) i 30 rocznica zjednoczenia polskiego ruchu robotniczego. Zorganizowano około 12 tys. okolicznościowych wystaw książki i prasy, blisko 11 tys. spotkań z autorami książek, publicystami i działaczami politycznymi, ponad 900 wieczornic i zajęć klubowych poświęconych literaturze społeczno-politycznej. Przeprowadzono około 700 konkursów i quizów czytelniczych; czynnych było około 2000 kiermaszów i specjalnych stoisk sprzedaży literatury społeczno-politycznej. Najwięcej imprez firmowała Robotnicza Spółdzielnia Wydawnicza Prasa - Książka - Ruch (około 20 tys.). Księgarnie Domu Książki zorganizowały 1230 kiermaszów w różnych środowiskach (zakłady pracy, szkoły, uczelnie wyższe, środowiska wiejskie), 1050 wystaw połączonych ze sprzedażą oraz 250 spotkań z autorami i publicystami. Obrót książką społeczno-polityczną wyniósł ponad $18 \mathrm{mln}$ zł. W Częstochowie 20 listopada otwarta została centralna wystawa książki społeczno-politycznej (około 2,5 tys. pozycji). Oprócz niej - zainaugurowano wystawy: plakatu politycznego oraz Wydawnictwa KiW. W sali konferencyjnej częstochowskiej Cepelii odbyło się 12 spotkań ze znanymi naukowcami, publicystami i działaczami politycznymi. Znaleźli się wśród nich między inymi: prof. Marian Dobrosielski, prof. Andrzej Feliks Grabski, Edmund Osmańczyk, Wilhelm Szewczyk i Janusz Przymanowski. Ponadto w największych zakładach regionu miały miejsce okolicznościowe spotkania z udziałem ok. 4 tys. osób (w cyklu „Rozmowy o Polsce”) 25 .

${ }^{24}$ Dni książki zaangażowanej. Spotkanie w MKiS, „Przegląd Księgarski i Wydawniczy", 1969, nr 6.

${ }_{25}$ AAN, KC PZPR, Wydział Kultury, LVI-705, Sprawozdanie z XII Dni Książki „Człowiek - Świat - Polityka”, k. nlb.; SZW, Po Dniach Ksiażki Społeczno-Politycznej, „Przegląd Księgarski i Wydawniczy”, 1979, nr 1. Podobne informacje dla lat 1976-1979 -zob. A. Zalewska, X Dni Ksiażki ,,Człowiek - Świat-Polityka” (Próba bilansu), „Przegląd Księgarski i Wydawniczy”, 1976, nr 21-24; Czlowiek-Świat-Polityka, ,Przeglad Ksiegarski i Wydawniczy”, 1978, nr 1; AAN, KC PZPR, Wydział Kultury, LVI-1790, Sprawozdanie z przebiegu XIII Dni Książki „Człowiek - Świat - Polityka”, Warszawa styczeń 1980, k. nlb. 
Organizacja centralnych imprez inaugurujących Dni odbywała się wówczas w nowo utworzonych (w 1975 r.) miastach wojewódzkich (w $1976 \mathrm{r}$. w Lesznie, w 1977 r. - w Suwałkach, w 1978 r. - w Częstochowie, w 1979 r. - w Legnicy), co miało podnieść ich prestiż ${ }^{26}$.

W latach osiemdziesiątych impet organizacyjny wyraźnie opadł. Wskazuje na to szczególnie analiza sprawozdawczości z okresu stanu wojennego. W 1982 r. przygotowano tylko 53 kiermasze (z powodu słabego zaopatrzenia Domu Książki w odpowiednie wydawnictwa). Mniejsze „wystawki” zostały urządzone przez wojewódzkie Biblioteki Publiczne, ponadto odnotowano 762 ekspozycje w księgarniach i 23 poza lokalami księgarskimi. Największą z nich otwarto w warszawskim Domu Książki Uniwersus (zaprezentowano ponad 500 tytułów) ${ }^{27}$. W dokumentach partyjnych jednak pojawiła się wówczas nuta krytyki koncepcji Dni. Analizując ich przebieg w latach 1980-1982 i porównując z okresem wcześniejszym stwierdzano, że do roku 1979 roku organizowane były z ,ogromnym rozmachem”. Istniał Ogólnopolski Komitet Dni przy Departamencie Bibliotek Domów Kultury i Działalności Społeczno-Kulturalnej Ministerstwa Kultury i Sztuki oraz jego odpowiedniki w województwach. W 1980 ,uległa zmianie sytuacja społeczno-polityczna i nie było klimatu by kontynuować dni i upowszechnianie literatury społeczno-politycznej w dotychczasowym schemacie organizacyjnym". Z krytyką wielu działaczy spotkały się centralne wystawy inauguracyjne (duże koszty, efekty niewielkie) - bo charakter imprezy ,był bardziej propagandowy i spektakularny a frekwencję trzeba było często na siłę organizować"28.

Nie wydaje się jednak, żeby elementy krytyki pojawiające się w gremiach partyjnych zmieniły scenariusz imprez organizowanych w ramach DKS-P. W następnych latach nadal urządzano centralne inauguracje i wystawy w miastach wojewódzkich dobieranych pod katem aktualnych celów politycznych. I tak np. w 1985 r., w związku z obchodami 40-lecia, jak to wówczas formułowano, ,powrotu Ziem Zachodnich i Północnych do Macierzy" odbyły się one w Szczecinie. Ponadto wiele wystaw, kiermaszów i spotkań zorganizowano w zakładach pracy regionu (m.in. w Stoczni im. Warskiego i Zakładach Chemicznych w Policach) ${ }^{29}$.

${ }^{26}$ A. Zalewska, Ksiażka społeczno-polityczna - w centrum uwagi, „Przegląd Księgarski i Wydawniczy”, 1980, nr 1-2.

${ }^{27}$ AAN, KC PZPR Wydział Kultury, LVI-1494, Dni Książki Człowiek - Świat Polityka 1982 r. Informacja sporządzona na podstawie materiałów nadesłanych do KC PZPR przez KW PZPR, k. nlb.

${ }^{28}$ AAN, KC PZPR, Wydział Kultury, LVI-1791, Dni Książki „Człowiek -Świat Polityka"'[1983], k. nlb.

${ }^{29}$ AAN, KC PZPR, Wydział Ideologiczny, XXXV-239, Sprawozdanie z XIX dni książki społeczno-politycznej „Człowiek - Świat - Polityka”, k. nlb. 
Rok później Dni zainaugurowano we Wrocławiu. W związku z ogłoszeniem przez ONZ roku 1986 Rokiem Pokoju we wrocławskim Ratuszu przedstawiona została odpowiednia wystawa. Obchody uświetniała sesja naukowa na temat funkcji książki społeczno-politycznej z referatami dr. Stefana Kubówa, E. Adamowicza, dr. Józefa Wojtala i wstępem prof. Jana Trzynadlowskiego. Liczba i formy imprez niewiele różniły się od tych z roku poprzedniego. Co warto jednak podkreślić samokrytycznie stwierdzono, że wiele $\mathrm{z}$ nich spotkało się z niewielkim zainteresowaniem odbiorców. Postulowano, aby na przyszłość w większym stopniu zmobilizować znanych pisarzy, publicystów, uczonych i dziennikarzy. Jak dotąd - twierdzono - przedstawiciele opiniotwórczych środowisk nie wykazuja chęci uczestniczenia w tego rodzaju działaniach.

Ponadto zdarzało się (jak w województwie radomskim), że na spotkania w ramach Dni przyjeżdżali publicyści mniej znani, co negatywnie wpływało na frekwencję i promocję publikacji. Mimo wystaw i propagandy, narzekano na słaby odbiór publikacji społeczno-politycznych przez młodzież, zwłaszcza w szkołach ponadpodstawowych ${ }^{30}$.

Ta ostatnia uwaga jest tym bardziej istotna, że w założeniach programowych Dni to właśnie młodzież, obok robotników, miała stanowić głównego adresata organizowanych imprez. W wytycznych na XVIII Dni w 1984 r. pisano: „Oferta skierowana do młodzieży powinna uwzględnić nie tylko zainteresowania tego pokolenia, ale skutki manipulowania jego świadomością przez antysocjalistyczne siły" ${ }^{31}$. Tym najważniejszym antidotum miały być... dzieła klasyków marksizmu-leninizmu.

\section{Kanon literatury społeczno-politycznej: podstawa źródłowa}

Kwestią o znaczeniu podstawowym dla podjętych rozważań jest ustalenie, jakie wysiłki podejmowały władze partyjne/państwowe dla stworzenia kanonu lektur społeczno-politycznych? Czy takie kanony (zestawy, listy) powstały? Jak się one zmieniały?

Odnaleziony materiał źródłowy pozwala na udzielenie przynajmniej wstępnych odpowiedzi na te pytania. Wnioskowanie na ten temat jest możliwe dzięki dotarciu do kilku rodzajów dokumentów.

Po pierwsze są to zestawy lekturowe przygotowywane dla uczestników Klubu Książki Człowiek - Świat - Polityka. Ten pomysł na propagowanie

${ }^{30}$ AAN, KC PZPR, Wydział Kultury, LVI-1795, Sprawozdanie w XX Dni Książki Społeczno-Politycznej „Człowiek - Świat-Polityka” - 1986, k. nlb.

${ }^{31}$ AAN, KC PZPR Wydział Kultury, LVI-1792, Wytyczne na XVIII Dni Książki „Człowiek - Świat -Polityka”, Rada ds. Książki społeczno-Politycznej przy KC PZPR, Warszawa, lipiec 1984, k. nlb. 
tego typu wydawnictw narodził się w 1968 r. i był przedstawiany jako inicjatywa środowiska księgarskiego, poparta przez zainteresowane wydawnictwa, która ,znalazła zrozumienie” Ministerstwa Kultury i Sztuki i KC PZPR. Polegał on na tym, że członkowie klubu z przesłanych im 30 propozycji wydawnictw winni zamówić co najmniej sześć tytułów lub książki za minimum 200 zł, co dawało im prawo do premii w postaci siódmej książki (z możliwością wyboru z pięciu tytułów nowości) i specjalnych bonów. Ponadto w każdym województwie miała być wyznaczona tzw. księgarnia klubowa - odpowiednio duża i przystosowana do sprzedaży wysyłkowej ${ }^{32}$.

W latach następnych ten sposób popularyzacji literatury społeczno-politycznej był kontynuowany na podobnych zasadach ${ }^{33}$. Według informacji, które można odnaleźć w prasie księgarskiej w 1969 r. zgłosiło się do Klubu 22190 osób, 1970 r. - 66 079, 1971 r. - 49 237, 1972 r. - 26814 , 1973 r. 24780,1974 r. $-24503,1975$ r. $-28958,1976$ r. $-28959,1977$ r. -22550 , 1978 r. - 21 276. Malejące wyraźnie po okresie boomu lat 1970-1971 zainteresowanie tą inicjatywą mogło wynikać nie tylko z małej atrakcyjności książek klubowych. Szwankowała coraz bardziej organizacja. W 1974 r. piętnowano nagminne przesuwanie terminów lub wręcz odstępowanie od wydawania książek, które zostały umieszczone w zestawie klubowym. W 1969 r. nie ukazał się tylko jeden z tych tytułów, w 1970 - już trzy, w 1971 - cztery, w 1972 - pięć, w 1973 - sześć. W roku 1970 w pierwszym kwartale ukazało się osiem tytułów zamiast zapowiedzianych 17, w ciagu trzech kolejnych kwartałów tego roku - zamiast zapowiedzianych 41 - jedynie 30. W latach 1969-1973 w edycjach klubu książki nie zrealizowano 86830 konkretnych zamówień książek ${ }^{34}$. Te wszystkie trudności powiększyła na początku lat osiemdziesiątych malejąca produkcja książek, co spowodowało, że z realizacji koncepcji klubu wówczas zrezygnowano ${ }^{35}$.

Publikowane w ramach kolejnych edycji Klubu listy książek dla jego członków nie sąjedynymi, na podstawie których można próbować wnioskować o charakterze kanonu upowszechnianej literatury społeczno-po-

${ }^{32}$ T. H., Klub ksiązki ,, Człowiek - Świat-Polityka”, „Przegląd Księgarski i Wydawniczy”, 1968, nr 19; AAN, KC PZPR, 237/VIII-1102, Założenia organizacyjne Klubu Książki „Człowiek - Świat - Polityka” 1969 r., k. 27.

${ }^{33}$ Zob. m.in. AAN, KC PZPR Wydział Kultury, LVI-717, Informator Klub Książki Człowiek Świat Polityka 1977, Zjednoczenie Księgarstwa 1977, k. nlb.; AAN, KC PZPR, Wydział Kultury LVI-1790, Informator. Klub Książki „Człowiek - Świat - Polityka” 1979, Zjednoczenie Księgarstwa, Warszawa 1978, k. nlb.; Klub Ksiażki 1973, „Przegląd Księgarski i Wydawniczy”, 1972, nr 19-20.

${ }^{34}$ D.M., U progu siódmej edycji „Klubu”, „Przegląd Księgarski i Wydawniczy”, 1974, nr 18.

35 AAN, KC PZPR, Wydział Kultury, LVI-1791, Dni Książki „Człowiek - Świat Polityka" [1983], k. nlb.. 
litycznej. Poza tymi wykazami corocznie sporządzano znacznie obszerniejsze zestawy książek, które miały być propagowane w ramach Dni. Były one ustalane w porozumieniu z wydawnictwami. Specjalny katalog książek tego typu przygotowywała (i to na wiele lat przed zainicjowaniem DKS-P) Składnica Księgarska ${ }^{36}$. Odpowiednie wydziały KC PZPR dbały o to, aby informacje o nich znalazły się w recenzjach i informacjach prasowych i telewizyjnych ${ }^{37}$.

\section{Partyjne instrumentarium do spraw książki społeczno-politycznej}

Dla odtworzenia sposobu myślenia odpowiedzialnych za tworzenie tych zestawów szczególne znaczenie mają wszelkie dokumenty dotyczące pracy gremiów kierowniczych zajmujących się propaganda książki społeczno-politycznej. Już pisząc o genezie Dni wzmiankowałem o powołaniu w 1959 r. Komisji Literatury Społeczno-Politycznej przy Wydziale Propagandy i Agitacji KC PZPR. W 1963 r. powstała przy tym Wydziale specjalna Komisja do spraw oceny literatury politycznej, która przygotowała materiały do dyskusji na naradzie poświęconej ocenie wydawnictw społeczno-politycznych zorganizowanej 5 czerwca $1963 \mathrm{r}$. Wzięli w niej udział przedstawiciele wszystkich najważniejszych oficyn działających w Polsce ${ }^{38}$.

${ }^{36}$ Świadczy o tym „Lista nr 1 podstawowego asortymentu literatury społeczno-politycznej”, opublikowana w „Pracy Księgarskiej” w 1960 r. (nr 32). Był to zestaw tytułów zatwierdzony przez Ministerstwo Kultury i Sztuki jako „minimum asortymentu książek społeczno-politycznych, obowiązujące wszystkie księgarnie Domu Książki”. Zob. również: A. Zalewska, Ksiażka spoleczno-polityczna..., dz. cyt.

${ }^{37}$ AAN, KC PZPR, Wydział Propagandy, Prasy i Wydawnictw, XXXII-10, VII Dekada Książki Społeczno-Politycznej „Człowiek-Świat-Polityka”. Wybór tytułów z katalogu „Człowiek - Świat - Polityka” 1973 wydanych od listopada 1972 do listopada 1973 r. proponowanych do uwzględnienia w recenzjach i informacjach prasy i TV, Warszawa, 6 listopada 1973, k. 85-87. W dziale historia w tym wyborze znalazły się m.in. następujące publikacje: Polski czyn zbrojny w latach II wojny światowej, t. IV, Wydawnictwo MON; Z. Stapor, Bitwa o Berlin, Wydawnictwo MON; Z Flisowski, Pomorze - reportaż z pola walki, Wydawnictwo MON; M. Juchniewicz, Polacy $w$ radzieckim ruchu podziemnym i partyzanckim, Wydawnictwo MON; N. Kołomejczyk, Rewolucje ludowe w Europie 1939-1948, Wiedza Powszechna; J. Marchlewski, Ludzie, czasy, idee, KiW; W. i R. Sliwowscy, Aleksander Hercen, PIW; E. Osmańczyk, Chwalebna wyprawa na Berlin, KiW; S. Szmaglewska, Niewinni w Norymberdze, KiW; D. Proektor, Agresja i katastrofa, KiW; Historia KPZR, t. 3, KiW; red. J. Topolski, Dzieje Wielkopolski, t. 1, Wydawnictwo Poznańskie; red. W. Jakóbczyk, Dzieje Wielkopolski, t. II, Wydawnictwo Poznańskie; W. Czujkow, Gwardziści spod Stalingradu, Wydawnictwo MON; G. Żukow, Wspomnienia i refleksje, Wydawnictwo MON; H. Rechowicz, Konsekwentna lewica. Komunistyczna Partia Polski, Wiedza Powszechna; A. Czubiński, Kraj Rad. Lata zmagań i zwycięstw, Iskry.

${ }^{38}$ AAN, KC PZPR, 237/VIII-467, Zaproszenie Wydziału Propagandy i Agitacji KC PZPR do udziału w pierwszym posiedzeniu Komisji ds. oceny literatury politycznej, 
W latach późniejszych nie udało się natrafić na ślady istnienia w ramach struktur partyjnych specjalnych gremiów, które systematycznie zajmowałyby się tylko sprawami literatury społeczno-politycznej. Być może uznawano, że wysiłek odpowiednich wydziałów KC przy organizacji kolejnych edycji DKS-P, nie wymagał tworzenia takich gremiów.

Zmiana tego stanowiska dokonała się w latach osiemdziesiątych. Szerokie poparcie dla „Solidarności”, budowa zaczątków społeczeństwa obywatelskiego - wszystko to razem kazało postawić pytanie o skuteczność dotychczasowej propagandy partyjnej. Stan wojenny, kryzys polityczny i społeczno-gospodarczy tworzyły kolejne pola konfliktów między dużymi grupami społecznymi a władza. W tej sytuacji konieczność przekonywania do własnych racji, szukania poparcia dla partyjnych wizji przemian w Polsce skłaniała do przemyślenia na nowo roli, jaka w tych procesach winna przypaść literaturze społeczno-politycznej. Ponadto należało zastanowić się nad spadkiem roli Dni, jako tradycyjnej kampanii propagandowej, jaki nastapił od 1980 roku.

Najpewniej takie ogólne przesłanki leżały u podstaw decyzji o powołaniu w 1984 r. Rady ds. Książki Społeczno-Politycznej jako ciała doradczego Sekretariatu KC PZPR w sprawach „kompleksowo traktowanej polityki wydawniczej partii w zakresie literatury społeczno-politycznej w Polsce" ${ }^{39}$. Na jej czele staną sekretarz KC Henryk Bednarski ${ }^{40}$.

W tych ogólnie ustalonych ramach rada zajmowała się m.in. wypracowaniem założeń programowych i organizacyjnych kolejnych DKS-P. Dokonywała również oceny stanu publikacji w tym zakresie oraz ustalała priorytety wydawnicze na przyszłość i formułowała zalecenia dla instytucji państwowych, w tym przede wszystkim dla Ministerstwa Kultury i Sztuki.

Impulsem do jej utworzenia były również mało optymistyczne informacje dotyczące kondycji literatury społeczno-politycznej w pierwszej połowie lat osiemdziesiątych. Wynikało z nich, że po kryzysie lat 19801981 nastapił wzrost liczby wydanych egzemplarzy, ale liczba tytułów malała: o ile w roku 1979 - opublikowano 2280 tytułów książek zaliczo-

k. 12; AAN, KC PZPR237/VIII-468, [Stenogram narady poświęconej ocenie wydawnictw społeczno-politycznych zorganizowanej przez Wydział Propagandy KC PZPR] 5 VI 1963, k. 17 i n.

${ }^{39}$ AAN, KC PZPR Wydział Ideologiczny, XXXV-237, Sekretarz KC Henryk Bednarski do towarzyszy I Sekretarzy KW PZPR Warszawa, 1.09. 1984, k. nlb.

${ }^{40}$ K. Molek, Przed XIX Dekada Ksiażki Społeczno-Politycznej „, Człowiek Świat - Polityka”, „Przegląd Księgarski i Wydawniczy”, 1985, nr 7-8. AAN, KC PZPR, LVI-1793, Założenia programowe i organizacyjne XIX Dni Książki SpołecznoPolitycznej „Człowiek - Świat - Polityka”, Rada ds. Książki Społeczno-Politycznej przy KC PZPR, Warszawa lipiec 1985, k. nlb. 
nych do tej grupy (39,2 tys. arkuszy wydawniczych, 27,9 mln egz. nakładu), to w 1982 r. - tylko 1832 (30,8 tys. arkuszy, 37,4 mln egz.), a w roku 1983 odpowiednio - 1768 (32,2 tys. ark., 39,4 mln egz.). Najważniejszą rolę $\mathrm{w}$ wydawaniu tej literatury pełniły wówczas oficyny: KiW, MON i PWN, publikując 37\% tytułów, 43\% arkuszy i 56\% nakładów literatury społeczno-politycznej.

Tendencje spadkowe w zakresie liczby tytułów miały wynikać nie tylko z braków materiałowych (papier) i mechanizmów reformy gospodarczej w poligrafii. Zawodzili również autorzy, którzy często nie wywiązywali się z umów, a nagminnie $\mathrm{z}$ terminów. Według funkcjonariuszy Wydziału Ideologicznego KC PZPR stan nauk społecznych i podziały polityczne w środowiskach naukowych powodowały, że wydawcy partyjni obracali się w wąskim kręgu autorów. W tej sytuacji wykonanie zamówień przekraczało ich możliwości czasowe, tym bardziej, że pisanie książki społeczno-politycznej było traktowane jako praca dodatkowa (obok naukowej, dydaktycznej, dziennikarskiej, politycznej itp.). Długość cyklu wydawniczego (w KiW w 1980 r. średnio 318 dni, w 1982 - 467 dni) powodowała $\mathrm{W}$ znacznej liczbie przypadków częściową lub całkowita dezaktualizacje pozycji. Niskie nakłady czyniły jej wydawanie dodatkowo nieopłacalnym ${ }^{41}$.

Rada ds. Książki Społeczno-Politycznej w marcu 1985 r. zajęła się analizą i oceną działalności wydawniczej z zakresu literatury religioznawczej i światopoglądowej w latach 1982-1985. Omawiano także plany wydawnicze dotyczące wzmiankowanej literatury do $1990 \mathrm{roku}^{42}$. Była to zresztą kontynuacja coraz bardziej intensywnego zajmowania się upowszechnianiem tego typu publikacji przez kierownictwo partii. Jej etapem była m.in. narada 12 wydawnictw zwołana przez Wydział Kultury KC jeszcze w styczniu 1984 r. W jej efekcie wprowadzono do planów wydawniczych w 1984 r. 14 pozycji o charakterze ,filozoficzno-światopoglądowym"43.

\footnotetext{
${ }^{41}$ AAN, KC PZPR Wydział Ideologiczny, XXXV-237, Informacja o działalności wydawniczej i upowszechnieniu literatury społeczno-politycznej [1984], k. nlb.

${ }^{42}$ Dalsze omówienie narady i cytaty - na podstawie: AAN, KC PZPR, LVI-1476, Notatka o posiedzeniu Rady ds. Książki Społeczno-Politycznej przy KC PZPR, k. nlb.

${ }^{43}$ Były to: Tadeusza Brezy Spiżowa brama (Czytelnik, 50 tys. egz.) i Urzad, Anatole'a France'a Bunt aniołów (Czytelnik, 50 tys. egz.), Jana Parandowskiego Niebo w płomieniach (Czytelnik, 50 tys.), Ignacego Krasickiego Monachomachia (Czytelnik, 20 tys. egz.), Jezrego Cepika Jak czlowiek stworzył bogów (Nasza Księgarnia, 30 tys.), Ethel Voynich Szerszeń (Iskry,100 tys.); Tadeusza Kotarbińskiego Medytacje o życiu godziwym (Wiedza Powszechna, 30 tys. egz.,), André Gide'a Lochy Watykanu (Wydawnictwo Literackie, 50 tys. egz.), Charlesa Reade'a Klasztor i miłość, (Wydawnictwo Literackie, 50 tys. egz.), Denisa Diderota Zakonnica (Ludowa Spółdzielnia Wydawnicza, 20 tys.
} 
Taki wybór tematyki obrad marcowego posiedzenia Rady nie wydaje się więc czymś nowym i przypadkowym. Nie chodziło tylko o to, że ta problematyka była „od zawsze” ważnym segmentem tego, co nazywano literaturą społeczno-polityczna, ale również o osłabienie wywołanego wyborem Polaka na papieża wzrostu religijności i coraz większej roli Kościoła katolickiego w życiu społecznym. Stwierdzono, iż w latach 1982-1985 nakłady publikacji literatury światopoglądowej i religioznawczej utrzymały się na zbliżonym poziomie. Mimo planowanego wzrostu w 1985 r., oferta była niezadowalająca zarówno pod względem atrakcyjności, różnorodności tematycznej, jak i ,w dziedzinie edytorskiej i wysokości nakładów". Te negatywne skutki pogłębiała zła sytuacja w przemyśle poligraficznym. Szczególnie niepokoiła radę „ofensywna działalność edytorska związków wyznaniowych", które systematycznie zwiększały liczbę wydawanych tytułów, jak i wysokość nakładów, o czym przekonywało załączone zestawienie.

Tabela 2. Literatura religioznawcza i światopoglądowa w latach 1982-1985

\begin{tabular}{|c|c|c|c|c|c|c|c|c|}
\hline \multirow{3}{*}{ Rok } & \multicolumn{4}{|c|}{ Wydawnictwa świeckie } & \multicolumn{4}{|c|}{ Wydawnictwa wyznaniowe } \\
\hline & \multirow{2}{*}{ tytuły } & \multirow{2}{*}{ nakłady } & \multicolumn{2}{|c|}{ w tym pow. 50 tys. } & \multirow{2}{*}{ tytuły } & \multirow{2}{*}{ nakłady } & \multirow{2}{*}{$\begin{array}{l}\text { w tym pow. } \\
50 \text { tys. egz. } \\
\text { tytuły }\end{array}$} & \multirow[b]{2}{*}{ nakłady } \\
\hline & & & tytuły & nakłady & & & & \\
\hline 1982 & 89 & 1788500 & 8 & 769400 & 482 & 7050100 & 20 & 1764980 \\
\hline 1983 & 63 & 1877200 & 10 & 1206400 & 491 & 8593800 & 35 & 2667410 \\
\hline 1984* & 71 & 1856670 & 11 & 971500 & 476 & 8448400 & 9 & 551000 \\
\hline 1985 & 107 & 4007300 & 37 & 2730000 & 602 & 11222000 & 41 & 3230000 \\
\hline
\end{tabular}

* dane za rok 1984 w zakresie produkcji wydawnictw wyznaniowych - orientacyjne.

Przypominano, że w tych latach wydawanie dzieł klasyków marksizmu-leninizmu o tej tematyce było możliwe dzięki wsparciu materialnemu i merytorycznemu radzieckiego ruchu wydawniczego. $\mathrm{W}$ rezultacie

egz.), Voltaire'a Powiastki filozoficzne (PIW, 30 tys. ezg.) i Traktat o nietolerancji, Tadeusza Boya-Żeleńskiego Reflektorem w mrok (PIW, 50 tys. egz.). Zob. AAN, KC PZPR, Wydział Kultury LVI-1477, Informacja o realizacji zadania zwiększenia produkcji książek z dziedziny literatury filozoficzno-światopoglądowej, W. Kultury KC PZPR, Warszawa, 23 VII 1984, k. nlb. W tejże informacji stwierdzono, że do lipca 1984 r. ukazało się pięć książek o tej tematyce w łącznym nakładzie 480 tys. egzemplarzy. Były to: Dzieje ksiag Starego Testamentu Witolda Tylocha (KiW, 80 tys. egz.); Wzgórze Watykanusa Kazimeirza Sidora (KiW, 100 tys. egz.); Mitologia starożytnej Italii Aleksandra Krawczuka (Wydawnictwa Artystyczne i Filmowe, 20 tys. egz.); Reflektorem $w$ mrok T. Boya-Żeleńskiego, PIW (50 tys. egz.) i Kubuś Fatalista i jego pan D. Diderota (PIW, 50 tys. egz.). 
zaczęły się ukazywać popularne, monotematyczne wybory: $O$ moralności socjalistycznej, $O$ religii oraz nowe opracowanie 55-tomowej edycji Dziet wszystkich Lenina. W ramach własnych możliwości poligraficznych zakończono wydawanie „Popularnej Biblioteki Klasyków Marksizmu-Leninizmu".

Jako osiagnnięcie edytorskie w zakresie literatury filozoficznej traktowano wydanie w PWN-owskiej Bibliotece Klasyków Filozofii prac Georga Wilhelma Friedricha Hegla, Fryderyka Engelsa, György Lukacsa oraz wznowienie Zarysu historii filozofii Jana Legowicza. Pozytywnie oceniono również pierwsze polskie wydanie Słownika filozofii marksistowskiej (przez Wiedzę Powszechną w 1982 r.).

Wśród książek podejmujących problematykę etyczna jak ważne uznano wydanie poszerzonego i uzupełnionego leksykonu dla dzieci i młodzieży Wyrazy trudne, ważne i ciekawe, którego znaczna część haseł zawierała treści z „szeroko pojętej problematyki światopoglądowej” ${ }^{44}$.

Wśród publikacji religioznawczych i z zakresu polityki wyznaniowej zauważano kilka monografii naukowych poszczególnych religii (Prawosławie Józefa Kellera i Protestantyzm Stanisława Markiewicza) oraz książki z popularnych serii o religiach i mitologiach ludów i narodów z różnych regionów świata (,Mitologie świata” Wydawnictw Artystycznych i Filmowych i „,Religie świata" Krajowej Agencji Wydawniczej). Prawdziwym bestsellerem w tej grupie były wydawane w kilkusettysięcznych nakładach wznowienia Opowieści biblijnych i Opowieści ewangelistów Zenona Kosidowskiego. Narzekano na brak syntez naukowych z takich tematów jak zarys dziejów religii, historia Kościoła, czy słownikowych i encyklopedycznych opracowań religioznawczych. „Zwraca uwagę niedostatek publikacji naświetlających polityczne motywacje w działalności Kościoła katolickiego, stosunek Kościoła do marksizmu i socjalizmu, funkcjonowanie instytucji kościelnych w państwie: politykę wyznaniową w Polsce, a także publikacji dokonujących socjologicznej i historycznej analizy zjawiska religijności”.

Za najważniejsze osiagnięcie wydawnicze w zakresie literatury pięknej, służące ,upowszechnianiu laickich treści światopoglądowych” uznano ukazanie się... wyboru publicystyki Tadeusza Boya-Żeleńskiego Reflektorem w mrok w nakładzie 200 tys. egz. (w 1984 r. w Państwowym Instytucie Wydawniczym).

Rada uznała, że w związku z wprowadzeniem do programu szkół średnich przedmiotu „religioznawstwo” należy wesprzeć jego naucza-

${ }^{44}$ Książka Wyrazy trudne, ważne i ciekawe: leksykon dla dzieci i młodzieży została wydana w 1977 r. przez Wiedzę Powszechną. Kolejne wydania pochodzą z roku 1979 i 1980 . 
nie odpowiednim zestawem książek naukowych, popularno-naukowych i beletrystycznych, adresowanych zarówno do uczniów, jak i nauczycieli. Należy ogłosić konkurs na napisanie podręcznika do tego przedmiotu. ,Jednocześnie rozważenia wymaga, przy obecnym ostrym deficycie papieru, wielkość jego przydziałów dla Kościoła oraz jego dostęp do państwowych mocy poligraficznych. Ponownego rozpatrzenia wymaga również system preferencji celnych przy sprowadzaniu przez Kościół urządzeń i materiałów poligraficznych z zagranicy".

W załączniku do omawianego dokumentu zamieszczono listę 36 ,,znaczących tytułów z literatury religioznawczej i światopoglądowej”, które powinny ukazać się na rynku księgarskim w 1985 roku.

W zaleceniach Rady „W sprawie literatury światopoglądowej i religioznawczej” za konieczne uznano ,wykreowanie popularnonaukowych książek światopoglądowych dla dzieci i młodzieży oraz ich upowszechnienie". Chodziło przede wszystkim o książki przyrodoznawcze zawierające wiedzę o materialnym charakterze rzeczywistości, o powstaniu świata i życia na Ziemi, genezie człowieka, uczące o działaniu obiektywnych praw przyrody.

W perspektywicznym planie wydawniczym miało znaleźć się więcej publikacji podejmujących problematykę historii i historii porównawczej religii, krytycznych prac religioznawczych, z socjologii religii, pozycji charakteryzujących współczesną religijność polską oraz ,wskazujących na ideologiczne i polityczne aspekty religii, demaskujące fałszywość lansowanego przez Kościół mitu Polaka katolika".

Zalecano ponadto, aby wzbogacić plany wydawnicze o wznowienia najwartościowszych książek upowszechniających ,laicką kulturę humanistyczną" i zapewnić im preferencję w druku. Szczególnie należało zwrócić uwagę na dzieje „postępowej myśli” polskiego renesansu, Oświecenia i XIX wieku, tradycje myśli racjonalistycznej i materialistycznej, a także dzieje polskiej tolerancji. Postulowano, aby podobnej analizie poddać literaturę piękną polską i obca. W wyniku tych powinien powstać zestaw tytułów przeznaczonych do stałego wznawiania w masowych nakładach przez wytypowane wydawnictwa państwowe i spółdzielcze. Opracowaniem takiej listy winna zająć się przede wszystkim partyjna Akademia Nauk Społecznych. Dziełom tym miano zapewnić preferencję w druku i kolportażu ${ }^{45}$.

Kolejnym kierunkiem zainteresowań Rady, uzasadnionym przez podejmowane wówczas próby reformowania gospodarki była literatura ekono-

${ }^{45}$ AAN, KC PZPR Wydział Ideologiczny, XXXV-238, Zalecenia Rady ds. Książki Społeczno-Politycznej przy KC PZPR w sprawie literatury światopoglądowej i religioznawczej [1985], k. nlb. 
miczna. W ten sposób realizowano treści programowe przyjętej w lipcu 1984 r. uchwały Biura Politycznego w sprawie edukacji ekonomicznej społeczeństwa polskiego ${ }^{46}$. Podstawą do sformułowania stanowiska Rady w tej sprawie w 1985 r. było opracowanie Ministerstwa Kultury i Sztuki na temat publikacji z zakresu literatury społeczno-ekonomicznej wydanych w latach 1982-1985 oraz analiza zamierzeń edytorskich na lata 1986-1987.

Po zapoznaniu się z nimi zalecano podjęcie przez Ministerstwo Kultury i Sztuki zadań koordynacyjnych w sferze działalności programowej wydawnictw publikujących literaturę ekonomiczną. Programy wydawnicze miały szerzej niż dotąd uwzględniać kwestie „racjonalnego gospodarowania”, kierunki zmian strukturalnych w gospodarce Polski i funkcjonowanie mechanizmów reformy gospodarczej oraz tematykę historii gospodarczej Polski, a szczególnie jej historię najnowszą. Zalecano przygotowanie nowego podręcznika ekonomii politycznej socjalizmu i unowocześnienie treści $\mathrm{w}$ dotychczas wydanych ${ }^{47}$.

Oceniając dwa lata później realizację tych zaleceń Rada za sukces uznała wydanie pierwszej polskiej edycji Zarysu krytyki ekonomii politycznej Karola Marska i kontynuację nowej edycji Dzieł Lenina. Odnotowano również ukazanie się trzech książek na temat polskiej reformy gospodarczej (Andrzeja Karpińskiego, Grzegorza Kołodki, Stefana Marciniaka $^{48}$ ). Zapoznano się również z opiniami na temat serii wydawniczych: „Biblioteka Samorządu Robotniczego”, „ABC gospodarki”, „Biblioteka Nauki o Pracy” oraz „Ekonomia XX wieku” i postanowiono je przekazać wydawcom celem wykorzystania. Po stronie niepowodzeń wymieniano nadal brak nowych podręczników ekonomii politycznej socjalizmu dla studiów ekonomicznych oraz thumaczeń prac o tematyce gospodarczej z literatury radzieckiej i innych krajów socjalistycznych ${ }^{49}$.

\footnotetext{
${ }^{46}$ AAN, KC PZPR Wydział Ideologiczny, XXXV-240, Zalecenia Rady ds. Książki Społeczno-Politycznej przy KC PZPR w sprawie działalności wydawniczej dotyczącej realizacji programu edukacji ekonomicznej społeczeństwa, lipiec 1985, k. nlb.

47 Tamże.

48 Prawdopodobnie chodzi o prace: Andrzeja Karpińskiego, 40 lat planowania w Polsce: problemy, ludzie, refleksje, Warszawa 1986; Grzegorza Kołodki, Cele rozwoju a makroproporcje gospodarcze, Warszawa 1986 i Stefana Marciniaka, Dlugofalowe cele przedsiębiorstwa $i$ warunki ich realizacji, Warszawa 1986.

${ }^{49}$ AAN, KC PZPR Wydział Ideologiczny, XXXV-240, Ustalenia i wnioski Rady ds. Książki Społeczno-Politycznej w sprawie realizacji „Zaleceń” Rady z lipca 1985 oraz kierunków dalszego rozwoju działalności wydawniczej w zakresie literatury ekonomicznej przyjęte na posiedzeniu w dniu 26 czerwca 1987, k. nlb.
} 


\section{Kanon literatury społeczno-politycznej: trwałość i zmiany}

Aby jednak w sposób wyczerpujący odpowiedzieć na wcześniej postawione pytania o zmienność kanonów literatury społeczno-politycznej konieczna jest bardziej systematyczna i w miarę możliwości obejmująca jak najdłuższy okres analiza list (zestawów) książek do niej zaliczanych.

Jak już pisałem wcześniej, sporządzano je przy okazji organizowania DKS-P, a więc od 1967 roku. Dla okresu wcześniejszego nie dysponujemy podobnie szczegółowym materiałem źródłowym, co oczywiście nie oznacza, że takich zestawień wówczas nie tworzono. Wydaje się nawet, że w okresie stalinowskim mamy szczególną obfitość tej literatury, a zwłaszcza broszur. W początkowym okresie rządów W. Gomułki problem ten był przedmiotem zainteresowania wzmiankowanej partyjnej Komisji Literatury Społeczno-Politycznej, co sprawiło, że w jej dokumentach odnaleźć można informacje i opinie o publikowanych wówczas książkach zaliczanych do tej grupy. Ten różnorodny materiał uprawnia do kilku najważniejszych konkluzji ${ }^{50}$.

Po pierwsze publikacje zaliczane do kanonu tej literatury wykazywały stabilność lub zmienność w zależności przede wszystkim od problematyki, którą poruszały. Bodajże najbardziej stałym jego elementem były

${ }^{50}$ Jeżeli nie zaznaczono inaczej przedstawiona poniżej analiza zawartości list książek przeznaczonych do upowszechniania jako literatura społeczno-polityczna, z lat wybranych za reprezentatywne, została sporządzona na podstawie następujących dokumentów odnalezionych w wyniku kwerendy archiwalnej i prasowej: AAN, KC PZPR, 237/VIII-774, Dni Książki Człowiek - Świat - Polityka (wybór tytułów), Warszawa 20-30 listopad 1967, k. 13 i n.; AAN, KC PZPR, 237/VIII-1102, Lista książek klubu czytelniczego „Człowiek - Świat - Polityka” [na 1969], k. 30-31; Klub Ksiażki Człowiek - Swiat - Polityka w roku 1970, „Przegląd Księgarski i Wydawniczy”, 1969, nr 19; AAN, KC PZPR Wydział Kultury, LVI-1789, PP Powszechna Księgarnia Wysyłkowa. Klub Książki „Człowiek - Świat - Polityka” 1978, k. nlb.; Klub 1971, „Przegląd Księgarski i Wydawniczy” 1970, nr 20-21; Klub Ksiażki 1973, „Przegląd Księgarski i Wydawniczy”, 1972, nr 19-20; AAN, KC PZPR Wydział Kultury, LVI-717, Informator Klub Książki człowiek świat polityka 1977, Zjednoczenie Księgarstwa 1977, k. nlb.; AAN, KC PZPR Wydział Kultury, LVI-1791, Człowiek - Świat - Polityka '81, k. nlb.; tamże, Zestaw książek zgłoszonych przez wydawnictwa (poza Książką i Wiedza) na Dekadę Książki Społeczno-Politycznej „Człowiek - Świat - Polityka” 1982, k. nlb.; AAN, KC PZPR Wydział Kultury, LVI-1792, Wykaz wybranych tytułów publikacji zalecanych do popularyzacji podczas Dekady książki społeczno-politycznej „Człowiek - Świat Polityka” 1984, k. nlb.; AAN, KC PZPR, LVI-1476, Wykaz 36 tytułów literatury światopoglądowej i religioznawczej, które ukażą się w 1985 r., k. nlb.; AAN, KC PZPR, LVI-1795, Wykaz wybranych tytułów publikacji zalecanych do popularyzacji podczas dekady książki społeczno-politycznej „,Człowiek - Świat -Polityka” [1986], k. nlb.; tamże, Wykaz tytułów, które powinny być stale obecne w księgarniach i na wszystkich kiermaszach [1986], k. nlb.; AAN, KC PZPR Wydział Kultury, LVI-1798, Wykaz tytułów zalecanych do popularyzacji podczas dekady książki społeczno-politycznej „CzłowiekŚwiat-Polityka" 1987, k. nlb. 
dzieła „klasyków” ideologii komunistycznej: Karola Marksa, Fryderyka Engelsa i Włodzimierza Lenina. Stalina przestano traktować jako przynależnego do tej grupy wraz z odchodzeniem od jego kultu w ZSRR i państwach bloku wschodniego po XX Zjeździe KPZR w lutym 1956 roku. Zmieniające się ekipy władzy w Polsce komunistycznej uznawały zgodnie marksizm-leninizm za ideową podstawę swoich rządów. Nawet jeżeli uznamy, iż czyniły to coraz mniej z przekonania a coraz bardziej ze względów rytualnych, to i tak kolejne edycje dzieł tych autorów ukazywały się ze stosunkowo dużą systematycznością aż do 1989 r.

Dużo bardziej skomplikowany był problem z edycjami przemówień i innych prac przywódców partyjnych. W tym wypadku publikacje były bardziej uzależnione od koniunktur partyjnych. Sztandarowym przykładem na potwierdzenie tej tezy są losy publikacji W. Gomułki i o W. Gomułce.

Po odsunięciu go od władzy w sierpniu/wrześniu 1948 roku a następnie uwięzieniu w 1951 r. broszury jego autorstwa znalazły się w 1952 r. na listach książek usuwanych z bibliotek. Podobnie zresztą było z uznanymi za politycznie nieaktualne i niewygodne pracami mocno osadzonych w stalinowskim kierownictwie partii Romana Zambrowskiego i Hilarego Minca $^{51}$. Ponowne dojście Gomułki do władzy spowodowało m.in. publikację w masowych nakładach jego dzieł. Po raz kolejny „,zapomniano” o nim w okresie rządów Edwarda Gierka, by sobie na powrót przypomnieć po 1981 roku $^{52}$.

Kolejny trwały element omawianego kanonu to dzieła poświęcone tzw. filozofii marksistowskiej, walce z religią i Kościołem katolickim oraz propagujące postawy ateistyczne. W ,żelaznym” repertuarze książek społeczno-politycznych niezmiennie pojawiały się utwory na temat historii i współczesności ZSRR i innych krajów bloku wschodniego oraz międzynarodowego ruchu robotniczego.

Wśród książek na temat historii Polski wyróżniają się dwa nurty. Jeden stanowią dzieje PRL oraz polskiego ruchu robotniczego i lewicy społecznej, oświetlane przez głównie partyjnych historyków od lat sześćdziesiątych. Drugi nurt obejmuje prace naukowe i popularnonaukowe analizujące przeszłość państwa od czasów najdawniejszych, ale tematycznie i/lub interpretacyjnie ważne ze względu na aktualną ideologię państwową i ówczesne rozumienie racji stanu.

${ }^{51}$ S. A. Kondek, Papierowa..., s. 149.

${ }^{52}$ Zob. m.in.: D. Jarosz, Rok 1948 w historiografii Polskiej Rzeczypospolitej Ludowej i III Rzeczypospolitej, [w:] Zwrot polityczny '48. Między polska droga a projektem uniwersalnym, t. 1, red. nauk. M. Jabłonowski, W. Jakubowski, T. Krawczak, Warszawa 2013, s. 563-594. 
Bardziej szczegółowa analiza prac obecnych w zestawieniach literatury społeczno-politycznej ujawnia istotne problemy, które dotyczą w różnym stopniu wielu jej grup tematycznych.

Jeden z ważniejszych związany jest z jakością tych dzieł, mierzoną różnymi kryteriami $\mathrm{w}$ zależności od ich charakteru. Wszak oprócz prac o bieżącej polityce i „współczesnych zagadnieniach” świata i Polski, użytecznych w bieżącej propagandzie partyjnej, znalazły się tam opracowania naukowe i popularnonaukowe, zarówno zamawiane u autorów, jak i powstałe bez takich zachęt, bez kalkulacji co do ich wtłoczenia w ramy dobrze widzianej literatury społeczno-politycznej i profitów z tego wynikających.

To co wydaje się warte wskazania, to następująca w ciągu kilkudziesięciu lat Polski Ludowej ewolucja zmierzająca w kierunku ,unowocześnienia" kanonu literatury społeczno-politycznej oraz dostosowania go do gustów i potrzeb potencjalnych odbiorców.

Jednym z przykładów potwierdzających tę tendencję jest sposób traktowania tzw. literatury światopoglądowej. Jeśli pominąć nawet nawet zgrzebne i wulgarnie antyreligijne i antykościelne broszury z okresu stalinowskiego, to nawet to, co proponowano obywatelom PRL do czytania na temat religii i Kościoła katolickiego w Polsce i na świecie w latach sześćdziesiątych i w latach osiemdziesiątych, znacznie się różniło. W wyborze tytułów na XIII Dni Książki Społeczno-Politycznej z listopada 1967 roku, w dziale „Problematyka światopoglądowa. Laicyzacja życia społecznego. Zasady polityki wyznaniowej Polski Ludowej” znajdujemy tak różnorodne książki jak: Jerzego Ambroziewicza, Aleksandra Rowińskiego Postuchajże wierny ludu, Tadeusza Brezy Urzad, Tadeusza M. Jaroszewskiego, Nauka społeczna Kościoła a socjalizm, Józefa Kellera Szkice o moralności katolickiej, „nieśmiertelne” Opowieści biblijne Zenona Kosidowskiego, Stanisława Markiewicza Współczesne chrześcijaństwo w Polsce oraz Wiesława Mysłka Kościól katolicki i Tysiqclecie.

Jaki był punkt dojścia tej literatury w latach osiemdziesiątych? Jak już wcześniej wspomniałem, sprawa publikacji tzw. światopoglądowych była przedmiotem szczególnego zainteresowania władz centralnych PZPR, w tym również powołanej w 1984 r. Rady do Spraw Książki Społeczno-Politycznej. Z 1985 r. pochodzi „Wstępny wykaz tytułów z literatury naukowej, publicystyki oraz beletrystyki (polskiej i światowej) proponowany do wznowień lub nowych opracowań" ${ }^{33}$. Co ciekawe, zestawienie miało powstać na podstawie ekspertyzy partyjnej Akademii Nauk Spo-

\footnotetext{
${ }^{53}$ AAN, KC PZPR, Wydział Ideologiczny XXXV-238, k. nlb.
} 
łecznych, opracowania przedstawionego przez Departament Książki Ministerstwa Kultury i Sztuki oraz propozycji prof. Jerzego Adamskiego (wybitnego romanisty i krytyka literackiego) zgłoszonych na seminarium dla redaktorów wydawnictw publikujących literaturę religioznawczą i światopoglądową, które odbyło się w maju 1984 roku. Z notatką w tej sprawie miał się zapoznać gen. Wojciech Jaruzelski i ,zaakceptował jej treść merytoryczną" ${ }^{\circ 4}$.

To ze względu na antyklerykalizm postulowano opracowanie i wydanie wyboru prac religioznawczych Stefana Czarnowskiego oraz zbioru publicystyki Wincentego Rzymowskiego z wychodzącego w latach 19061931 pisma „Myśl Niepodległa”. Ponadto proponowano wznowienie m.in. takich prac jak: Psychologia religii Jana Władysława Dawida, Moralna podstawa sprawy polskiej Seweryna Goszczyńskiego, (,znanego z pamfletów antywatykańskich i antykatolickich"), Pięć wieków herezji oraz Matka Jezusa, matki bogów, królowe niebos Pawła Hulki-Laskowskiego, tomy: XI, XII i XIII wydania narodowego dzieł Adama Mickiewicza z 1953 roku, zawierające „mało znane wypowiedzi charakteryzujące go jako przeciwnika politycznego klerykalizmu", Chrześcijaństwo i katechizm Stanisława Witkiewicza i Wiara oświeconych Władysława Witwickiego.

Z uwagi na obecność wątków antyklerykalnych postulowano wznowienie wydań niektórych dzieł polskiej i europejskiej beletrystyki. Z prac polskich na tej liście znalazły się m.in. takie dzieła jak: Ład serca Jerzego Andrzejewskiego, Spiżowa brama, Urzad, Adam Grywatd i Mury Jerycha Tadeusza Brezy, Pałuba Karola Irzykowskiego, Zmory Emila Zegadłowicza, Klatwa Stanisława Wyspiańskiego, Matka Joanna od Aniołów Jarosława Iwaszkiewicza oraz... Ferdydurke Witolda Gombrowicza! Literatura obca jest tam reprezentowana przez Dekamerona Bocaccia, Stugę bożego i Poletko Pana Boga Erskina Caldwella, Kubusia Fataliste i jego pana Denisa Diderota, Lochy Watykanu Andre Gide'a, Gargantue $i$ Pantagruela Fraçoisa Rabelais'go, Żyda wiecznego tułacza Eugèna Sue, Klucze Piotrowe Rogera Peyrefitte'a oraz Diabła i Pana Boga JeanPaula Sartre'a.

Porównanie tych postulatów $\mathrm{z}$ ich realizacją wskazuje, że większość z tych książek do końca PRL nie zostało opublikowanych z przyczyn, których nie udało się ustalić. Mimo to przywołane propozycje pokazuja, jak daleko posunięte było,,nieortodoksyjne” było myślenie o takiej literaturze ze strony przynajmniej niektórych środowisk partyjnych.

\footnotetext{
${ }^{54}$ AAN, KC PZPR, LVI-1476, Notatka w sprawie wydawnictw antyklerykalnych, k. nlb.
} 
O istotnych zmianach kanonu literatury społeczno-politycznej w PRL świadczy również analiza porównawcza umieszczonych w nim prac historycznych.

W jej zestawach znajdują się prace różniące się nie tylko tematyką (co zważywszy na intencje władz można zrozumieć), ale również poziomem warsztatowym. Oto w 1967 r. wśród książek z historii Polski na jednym biegunie mieści się jednostronne, publicystyczne dzieło Stefana Arskiego My pierwsza brygada, a na drugim - Warszawa w powstaniu styczniowym Stefana Kieniewicza, Warszawa w powstaniu listopadowym Tadeusza Łepkowskiego oraz Państwo bez stosów Janusza Tazbira. Ów zestaw uzupełniały wówczas monografie Krystyny Kersten (Polski Komitet Wyzwolenia Narodowego 22 lipca - 31 grudnia 1944), Henryka Jabłońskiego (Polityka Polskiej Partii Socjalistycznej w czasie wojny 1914-1918), Jana Borkowskiego (Wizje społeczne i zmagania wiciarzy), Marii Turlejskiej (Rok przed klesska oraz Prawdy i fikcje), Aleksandra Skarżyńskiego (Polityczne przyczyny powstania warszawskiego), Krystyny Wyczańskiej (Polacy w Komunie Paryskiej) i Andrzeja Ajnenkiela (Od rzqdów ludowych do przewrotu majowego).

Ponadto obraz dziejów ojczystych w tym samym zestawie reprezentowały dzieła literackie Wojciecha Żukrowskiego (Dni klęski), Jana Gerharda (Łuny w Bieszczadach), Jerzego Putramenta (Wrzesień) i Mieczysława Moczara (Barwy walki).

Lista prac z najnowszej historii Polski wśród książek klubu „Człowiek - Świat - Polityka” na rok 1969 jest podobnie różnorodna i zdaje się wskazywać, że motywacje ich wyróżnienia mogły być dość złożone, zwłaszcza jeżeli weźmiemy pod uwagę szersze polityczne konteksty tego czasu. Rocznica wybuchu II wojny światowej spowodowała, że na wykazie znalazła się praca Marka Mariana Drozdowskiego, Alarm dla Warszawy. Obrona cywilna stolicy we wrześniu 1939 roku oraz tom Ponad ludzkq miarę. Wspomnienia operowanych w Ravensbrück. Ale już wydanie pracy Alfonsa Klafkowskiego Obozy koncentracyjne hitlerowskie jako zagadnienie prawa międzynarodowego można wiązać również z bieżącym kontekstem politycznym (sprawa tzw. encyklopedystów) ${ }^{55}$. Obraz wojny miały również kształtować: Bołdyn Jerzego Putramenta, Geneza Polskiej Partii Robotniczej Mariana Malinowskiego oraz Z kart naszej historii Władysława Gomułki.

Analiza zestawień uznanych za ważne książek z historii najnowszej Polski zarówno z tych lat, jak i okresów późniejszych, skłania do przypuszczenia, że

${ }^{55} \mathrm{Na}$ ten temat - zob. T. P. Rutkowski, Adam Bromberg $i$, ,encyklopedyści”. Kartka z dziejów inteligencji w PRL, Warszawa 2010. 
o ich wyróżnieniu mógł decydować temat i/lub osoba autora. To najpewniej ówczesne rozumienie polskiej racji stanu powodowało, że w zestawieniach literatury społeczno-politycznej po wielekroć pojawia się praca Gerarda Labudy Polska granica zachodnia. Tysiac lat historii, wydana po raz pierwszy w 1971 r. (choć nie bez trudności) ${ }^{56}$. Co do autorów, nie jest dziełem przypadku, że wśród nich grupy znaczące stanowili zarówno pracownicy partyjnych instytucji zajmujących się historią (szczególnie: Zakład Historii Partii przy KC PZPR, następnie Wyższa Szkoła Nauko Społecznych, a od 1985 r. Akademia Nauk Społecznych), jak i historycy - członkowie partii, zatrudnieni na uniwersytetach i w PAN. Wśród tych pierwszych natrafiamy najczęściej na nazwiska Norberta Kołomejczyka, Mariana Malinowskiego, Władysława Góry i Bogdana Hillebrandta.

W przypadku prac historycznych, podobnie jak wcześniej omawianych „antyklerykalnych” porównanie ich zestawów na przestrzeni kilkudziesięciu lat pokazuje daleko idącą ewolucję, która jest świadectwem postępującego, mimo trudności, poszerzania obszarów tematycznych i interpretacji uznanych za dozwolone. W tym sensie analiza tytułów książek zalecanych do popularyzacji może stanowić przyczynek do badań nad granicami wolności słowa w PRL. Ewolucja ta jest szczególnie widoczna, gdy porównamy przywołaną wcześniej listę książek z 1967 roku ze spisami, które powstały w końcowych latach PRL. Oto w 1987 r. , w kanonie tych lektur znajdują się książki, z których - jak dzisiaj wiemy - pewna część miała kłopoty cenzuralne, ale mimo to ostatecznie wyszły w kształcie, pozwalającym na wejście do aktualnego do dziś dorobku polskiej historiografii. Do nich zaliczyć należy chociażby takie prace jak m.in.: Niemcy $i$ okupacja hitlerowska w oczach Polaków: poglady i opinie z lat 1945-1948 Edmunda Dmitrówa, Pitsudczycy u władzy: dzieje Bezpartyjnego Bloku Wspótpracy z Rzqdem Andrzeja Chojnowskiego, Od Brześcia do maja Andrzeja Garlickiego, Polska polityka zagraniczna w latach 1918-1939 Marka Kamińskiego i Michała Zachariasa i Stanisław Cat-Mackiewicz 1896-1966: Wilno - Londyn autorstwa Jerzego Jaruzelskiego.

${ }^{56} \mathrm{O}$ tym, że wydanie nawet tego typu prac było uwikłane w bieżący kontekst polityczny świadczy pismo Naczelnego Dyrektora Naczelnego Zarządu Wydawnictw Jerzego Skórnickiego do kierownika Wydziału Propagandy i Agitacji KC PZPR Tadeusza Wrębiaka z 23 stycznia 1971 r. (AAN, KCPZPR, 237/XXI-6, k. 3-7, a więc tuż po odsunięciu od władzy Władysława Gomułki po obradach VII plenum KC PZPR. Skórnicki informował, iż zgodnie w poleceniem Wydziału wydawnictwa dokonały przeglądu „tytułów znajdujących się w tekach wydawniczych i produkcyjnych, w których mogą się znajdować informacje lub poglądy sprzeczne ze zmianami wynikającymi z uchwał VII plenum". Książka Labudy została wycofana z drukarni, gdyż - tak jak w kilku innych publikacjach - ,uwypuklona [w niej] jest rola W. Gomułki w odniesieniu do problemu granic, kwestii niemieckiej oraz spraw Ziem Zachodnich". 
Unowocześnieniu i liberalizacji ulegał również kanon prac z zakresu historii powszechnej. Stosunkowo najbardziej stabilny i zgodny z ideologiczną ortodoksją był zestaw prac dotyczących wschodniego sąsiada zwłaszcza, że ważną ich część stanowiły publikacje tłumaczone z języka rosyjskiego, na czele z dwukrotnie rocznicowo wydaną (w 1977 i 1987) Encyklopedia rewolucji październikowej.

W wypadku dziejów powszechnych, jako swoisty „punkt dojścia”, można potraktować zaproponowane w zestawie z 1987 r. takie prace jak: Historia społeczna Trzeciej Rzeszy Richarda Grunbergera, Historia nowożytnej kultury rosyjskiej Ludwika Bazylowa, Zasady w godzinie próby: wolnomularstwo w Europie Środkowo-Wschodniej 1929-1941 Ludwika Hassa oraz Wyniosła wieża: świat przed pierwsza wojna 1890-1914 Barbary Tuchman.

Jakie książki, mimo swojego bezsprzecznie „społeczno-politycznego” profilu, nie mogły wejść do partyjnego kanonu i z jakich przyczyn? Odpowiedź na te pytania wymaga bardziej szczegółowych badań, ale już wstępna kwerenda archiwalna wskazuje, że - poza pracami oczywistych wrogów systemu, których nie wydawano ex definitione - zależało to od zmieniających się kryteriów dotyczących zarówno treści dozwolonych, jak i opinii o aktualnej politycznej postawie autora. Dla udokumentowania tej tezy warto posłużyć się dwoma przykładami, pochodzącymi z różnych okresów PRL. Pierwszy dotyczy partyjnej selekcji wydawnictw na 50-lecie odzyskania niepodległości. W odpowiedniej notatce Wydziału Propagandy i Agitacji KC PZPR napisano, że zakwestionowano w całości i spowodowano zniszczenie składu przygotowywanej przez Państwowe Wydawnictwo Naukowe książki Jerzego Holzera Polska 1864-1939. Szkic historyczny. W pracy tej - argumentowano - w sposób fałszywy przedstawiono rolę SDKPiL i KPP, natomiast gloryfikowano PPSD oraz prawicę PPS. Zastrzeżenia wzbudzała ocena Józefa Piłsudskiego. "Praca zawierała wywody, w których oskarżano klasę robotniczą i chłopstwo o niejako wrodzony antysemityzm. W sumie książka była całkowicie sprzeczna z zasadami marksistowsko-leninowskiej historiografii i szkodliwa politycznie" 57 .

W tym samym czasie zakwestionowano i wstrzymano druk pracy Hanny i Tadeusza Jędruszczaków Ostatnie lata Drugiej Rzeczypospolitej. Publikacja zawierać miała wiele cennego materiału faktograficznego, zwłaszcza w części dotyczącej życia ekonomicznego i społecznego, ale

${ }^{57}$ AAN, KC PZPR, 237/VIII-1106, Notatka w sprawie realizacji wniosków Wydziału Propagandy i Agitacji KC PZPR dotyczących publikacji związanych z 50-leciem odzyskania niepodległości, Warszawa 22 IV 1969, k. 51. 
wiele tez ,jest jednak nie do przyjęcia”. Zarzuty dotyczyły szeregu ocen stosunków polsko-radzieckich, opinii o KPP oraz sposobu przedstawienia oblicza politycznego Józefa Piłsudskiego. „Autorzy w wielu momentach zatracili klasowe kryteria oceny zjawisk społeczno-ekonomicznych". Niesłuszna miała być również „również nasuwająca się z lektury książki teza, że polityka zagraniczna Polski przedwrześniowej była nieuniknioną i nie posiadającą alternatywy wypadkową układu sił politycznych w Europie" ${ }^{58}$. Uznano, że książka może ukazać się po poprawkach, na których część autorzy się zgodzili.

Zakwestionowano również całość wydania książki Marka Drozdowskiego Szkice z dziejów II Rzeczypospolitej (KiW). Powód: tom nierówny obejmujący prace wcześniej wydane, a niektóre tezy - fałszywe ${ }^{59}$.

Wyjście polegające na rozsypaniu nakładu czy nakazie wprowadzenia poprawek nie było jedynym, które stosowano. W przypadku wprowadzanych do księgarń w 1969 roku pamiętników Ignacego Daszyńskiego, których z przyczyn oczywistych nie można było poprawiać wybrano drogę pośrednią: Dyrektor Centrali Księgarstwa Dom Książki w lipcu 1969 r. zdecydował: „Wobec tego, że książka zawiera szereg szkodliwych politycznie ocen i uogólnień, będzie rozprowadzana przez «Dom Książki» na zasadach obowiązujących przy obrocie prohibitami”. Stworzono więc specjalny rozdzielnik osób publicznych, które mogły te pamiętniki kupić. $\mathrm{Na}$ szczeblu centralnym zaliczono do nich: członków KC i ich zastępców, członków rządu - ministrów i wiceministrów, członków Egzekutyw Komitetów Wojewódzkich PZPR, przewodniczących Prezydiów Wojewódzkich Rad Narodowych, aparat naczelny organizacji młodzieżowych, redaktorów naczelnych dzienników i czasopism partyjnych. Pracownicy nauki i inne osoby, niemieszczące się $w$ ramach tego wykazu a ubiegające o nabycie książki, zostały umieszczone na osobnych listach przekazywanych do akceptacji do Wydziałów Propagandy KW. Wspomnienia miały trafić również do wybranych książnic (Biblioteka Narodowa, biblioteki wojewódzkie oraz biblioteki wyższych uczelni prowadzące dział prohibitów, biblioteki instytutów naukowych podległych PAN $)^{60}$.

Kolejny przykład pochodzi z 1986 roku. Na opracowanym w Wydziale Kultury KC PZPR wykazie tytułów z planów wydawniczych 1986 i 1987 zespół zajmujący się literaturą społeczno-polityczną zgłosił wątpliwości

58 Tamże.

${ }^{59}$ Tamże.

${ }^{60}$ AAN, KC PZPR, 237/VIII-1106, Dyrektor Centrali Księgarstwa Dom Książki K. Majerowicz do KC PZPR Wydział Propagandy i Agitacji, Warszawa 3 VII 1969 , k. $74 \mathrm{in}$. 
co od celowości wydania (lub wznowienia) następujących książek: Andrzeja Broniarka Londyn i okolice, Tadeusza Lepkowskiego Powstanie listopadowe, Jana Strzeleckiego Ślady tożsamości, Tomasza Szaroty Okupowanej Warszawy dzień powszedni (wydanie III), Jerzego Tomaszewskiego Ojczyzna nie tylko Polaków. „Wyżej wymienieni autorzy uzasadniano to stanowisko - byli sygnatariuszami Listu 206 do Kongresu Intelektualistów w Warszawie" ${ }^{\text {". }}$ Z pewnością przedstawione przykłady nie są odosobnione.

\section{Literatura społeczno-polityczna i ,sowietskij faktor”}

W dotychczasowych publikacjach naukowych na temat polityki księgarsko-wydawniczej w Polsce po 1945 r. watek wpływu na nią ze strony Moskwy w zasadzie nie pojawia się jako samodzielny problem badawczy. Oczywiście przyjmuje się a priori, że system organizacyjny produkcji i dystrybucji książek był mniej lub bardziej wiernym odwzorowaniem rozwiązań radzieckich, że towarzysze zza wschodniej granicy wręcz ręcznie sterowali przenoszeniem doświadczeń ZSRR na grunt polski (vide: tworzenie struktur urzędu cenzury i zakreślenie jego kompetencji), ale na tych skądinąd słusznych konstatacjach się w zasadzie kończy. Tymczasem kwerenda przynajmniej niektórych dostępnych archiwaliów polskich i rosyjskich daje podstawy do uzupełnienia tych ogólnych opinii o szczegółowe ustalenia. Dotyczy to również problematyki księgarskowydawniczej, w tym publikacji książek społeczno-ekonomicznych.

Wynika z nich, że polityka gomułkowskiego ,porządkowania” polityki wydawniczej i usilnego promowania książki społeczno-politycznej nie była polską specyfiką w ramach bloku wschodniego. Wiele wskazuje na to, że impulsy wzmacniające (a niewykluczone, że inicjatywa) wyszły ze strony Moskwy. Odbywało się to w dwojaki sposób.

Pierwszy - to spotkania dwustronne osób oraz praca specjalnie stworzonych struktur organizacyjnych zajmujących się polsko-radziecką współpracą wydawniczą. Nawet z dalece wyrywkowych przekazów źródłowych wynika, że następowała wymiana doświadczeń na tym polu oraz że projektowano konkretne przedsięwzięcia.

${ }^{61}$ AAN, KC PZPR Wydział Kultury, LVI-197, Wykaz tytułów z planów 1986 i 1987 do których zgłoszono watpliwości co do celowości ich wydania, k. nlb. List 206 osób ze środowiska nauki i sztuki został wystosowany do uczestników rozpoczętego 19 stycznia 1986 r. w Warszawie Światowego Kongresu Intelektualistów w Obronie Pokojowej Przyszłości Świata. Jego sygnatariusze wskazywali gościom, że przybyli na zaproszenie rządu, który łamie prawa człowieka i do kraju, w którym są więźniowie polityczni. Autorzy listu prosili uczestników, aby stanęli w obronie tych osób. Zob. Kronika XX wieku, Warszawa 1991, s. 1242. 
Według dokumentów zachowanych w zespole akt KC PZPR, w grudniu 1968 r. starszy instruktor Wydziału Propagandy i Agitacji R. Paciorkowski oraz dyrektor i naczelny redaktor Wydawnictwa Literackiego Jerzy Skórnicki byli gośćmi Komitetu do spraw Prasy i Wydawnictw przy Radzie Ministrów ZSRR. Celem wizyty było zapoznanie się z planem wydawniczym na 100-lecie urodzin Lenina oraz nowymi inicjatywami radzieckimi w zakresie literatury społeczno-politycznej. Polscy goście odbyli rozmowy i zapoznali się z pracą Redakcji Literatury SpołecznoPolitycznej tego Komitetu oraz spotykali się z pracownikami wydawnictw: Politizdat, Sowietskaja Encyklopedia, Myśl, Młoda Gwardia oraz „Uzbekistan” (w Taszkiencie) ${ }^{62}$.

Od stycznia 1972 r., na przemian w ZSRR i Polsce, odbywały się posiedzenia polsko-radzieckiej grupy roboczej do spraw współpracy wydawniczej i księgarskiej. O tym, że książka społeczno-polityczna była jednym z najważniejszych tematów obrad, świadczy chociażby zachowany w aktach partyjnych protokół z dziesiątego posiedzenia tej grupy, która obradowała w lutym 1983 r. w Wiśle. Dokonano wówczas przeglądu efektów dotychczasowej współpracy. Stwierdzono, że w tylko w latach 1980-1982 w ZSRR wydano około 140 książek polskich autorów (literatura społeczno-polityczna i piękna) a w $P R L$ - 266 pozycji autorów radzieckich. W rezultacie tej współpracy opublikowano w Polsce m.in. tłumaczone z języka rosyjskiego „krótkie biografie” Karola Marksa (KiW 1979) i Fryderyka Engelsa (KiW 1980). Zgodnie z zaleceniami narady kierownictw ruchu wydawniczego krajów socjalistycznych (o czym piszę dalej) uczestnicy postanowili, że w Polsce wydawnictwem wiodącym w publikowaniu książek w serii „Ludzkość u progu XXI wieku” będzie „Wiedza Powszechna”, a w edytowaniu pozycji biblioteki „Socjalizm: współpraca i pomoc wzajemna" - Państwowe Wydawnictwo Ekonomiczne. Ustalono ponadto, że należy zwrócić szczególną uwagę na wydanie następujących wspólnych publikacji: Rewanżyzm: ideologia, praktyka (przez radzieckie Wydawnictwo Znamie oraz wydawnictwa NRD, PRL i CSRS) Styl i metody pracy aparatu partyjnego i państwowego (KiW i wydawnictwo Progress), Braterstwo broni (Wojenizdat - Wydawnictwo $\mathrm{MON})^{63}$.

${ }^{62}$ AAN, KC PZPR, 237/VIII-1106m Starszy instruktor Wydz. Propagandy i Agitacji KC R. Paciorkowski, dyrektor i naczelny redaktor Wydawnictwa Literackiego J. Skórnicki, Sprawozdanie z podróży służbowej do ZSRR, Warszawa 16 I 1969, k. nlb.

${ }^{63}$ AAN, KC PZPR, Wydział Kultury LVI-987, Protokół z dziesiątego posiedzenia stałej polsko-radzieckiej grupy roboczej ds. współpracy wydawniczej i księgarskiej, k. nlb. Zob. również: KC PZPR Wydział Kultury, LVI-958, Wykaz posiedzeń polskoradzieckiej mieszanej grupy roboczej, k. nlb. 
Koncepcje działań Kremla zmierzających do promocji wydawania literatury społeczno-politycznej były nie tylko elementem rozmów dwustronnych z Warszawą. Służyły temu organizowane od lat sześćdziesiątych XX wieku narady wydawców (i - rzadziej - księgarzy) krajów bloku wschodniego. Spotykali się na nich zarówno przedstawiciele kierowniczych organów ruchu wydawniczego tych krajów, jak i wydawcy różnego typu książek (encyklopedii, literatury naukowo-technicznej, popularno-naukowej, społeczno-politycznej, artystycznej, słownikowej itp.).

Sprawy książki społeczno-politycznej pojawiały się w trakcie obrad w dwojaki sposób. Po pierwsze, był to temat główny zarówno narad kierownictw ruchu wydawniczego jak i wydawców tej literatury. Oba typy spotkań nierzadko łączono, co świadczy o randze nadawanej publikacjom społeczno-politycznych w państwach bloku wschodniego. Po drugie, o tego typu publikacjach i sposobach ich upowszechniania dyskutowano przy okazji spotkań wydawców innego rodzaju książek oraz księgarzy.

Narady te były nie tylko forum dyskusji i przedstawiania odpowiednich sprawozdań, ale przede wszystkim kończyły się przyjęciem szczegółowych tzw. rekomendacji, zawierających plan konkretnych przedsięwzięć wydawniczych.

$\mathrm{Z}$ odnalezionych, dalece niekompletnych materiałów źródłowych wynika, że narada przedstawicieli organów wydawniczych państw bloku wschodniego odbyła się w 1967 r. w Moskwie, a dwie wcześniejsze w Budapeszcie i Sofii. Nieco więcej wiemy o kolejnym takim spotkaniu w dniach 22-24 kwietnia 1968 r. w Smolenicach na Słowacji, z udziałem delegatów z Bułgarii, Węgier, NRD, Mongolii, Rumunii, ZSRR, Czechosłowacji, Jugosławii i Polski. Omówiono m.in. kwestię wydań książek w związku ze 150 rocznicą urodzin Marksa, stuleciem urodzin Lenina i 25-leciem pokonania faszyzmu w Europie. Momentem konfliktowym spotkania była sprawa udziału przedstawiciela Czechosłowacji, który najpierw nie chciał przyjechać, a gdy jednak zdecydował się na udział - wyraził sceptycyzm co do możliwości przyjęcia wspólnego dokumentu. Jego zachowanie było najpewniej efektem rozbieżności miedzy Pragą a Kremlem w okresie praskiej wiosny. Mimo to rekomendacje udało się sformułować (choć przedstawiciel Czechosłowacji ich nie podpisał). Przewidywały one wymianę planów wydawnictw w związku ze stuleciem urodzin Lenina ${ }^{64}$.

Kolejna narada o tym charakterze odbyła się w dniach 9-13 grudnia 1969 r. w Berlinie. W przyjętych zaleceniach stwierdzano, że omówiono

${ }^{64}$ Rosijskij Gosudartvennyi Arkhiv Noveishei Isstorii (dalej: RGANI), f. 5, op. 60, ed.khr. 31, rolik 969600, Notatka Michajłowa, przewodniczącego Komitetu ds. Druku przy Radzie Najwyższej ZSRR, kwiecień 1968. 
stan przygotowań do planowanej na kwiecień - maj 1970 r. Międzynarodowej Wystawy Książki w Moskwie, poświęconej stuleciu urodzin Lenina oraz do Międzynarodowej Wystawy Sztuki Edytorskiej w Lipsku w 1971 roku. Pisano również, że literatura wydawana w latach poprzedzających naradę przez uczestniczące $\mathrm{w}$ niej kraje socjalistyczne była ,pomocna w walce przeciwko imperialistycznej ideologicznej dywersji i kontrrewolucji”, upowszechniała „nowoczesną wiedzę i jej naukowe zdobycze”, stanowiła aktywną pomoc w budowie socjalizmu. „Równocześnie zaleca się zwrócenie baczniejszej uwagi na problem światopoglądowego wzbogacenia literatury na gruncie marksizmu-leninizmu, dla zapobieżeniu ew. odideologizowania wydawanej literatury" ${ }^{\prime 5}$. Sprawą nierozstrzygniętą pozostało utworzenie w ramach RWPG grupy roboczej (sekcji), która zajmowała by się współpracą wydawniczą. Zalecano dokonanie wymiany planów wydawniczych z zakresu literatury związanej z 150 rocznicą urodzin Fryderyka Engelsa. Przyjęto wniosek, aby podczas Międzynarodowej Wystawy Książki w Moskwie zwołana została konferencja przedstawicieli państwowych i społecznych organów ruchu wydawniczego krajów socjalistycznych, na której dokonano by wymiany doświadczeń w zakresie wydań literatury, przygotowywanych z okazji setnej rocznicy urodzin Lenina ${ }^{66}$.

Wydaje się, że owo współdziałanie w związku z wymienionymi rocznicami przebiegało z pewnymi oporami, skoro polski delegat na naradzie berlińskiej w swym sprawozdaniu przyznawał, że przygotowanie publikacji na stulecie urodzin Lenina dało dobre rezultaty w ramach współpracy dwustronnej, ale niewielkie - w kooperacji multilateralnej ${ }^{67}$.

O konieczności współpracy przy wydawnictwach rocznicowych dyskutowano również na kolejnej naradzie kierownictw ruchu wydawniczego krajów socjalistycznych w Pradze (1-5 listopada 1971 r.). Przyjęto wówczas porozumienie o systematycznej koordynacji i uzgodnieniu działalności $\mathrm{w}$ związku $\mathrm{z}$ uczestnictwem $\mathrm{w}$ wystawach międzynarodowych, targach książki, sympozjach, szczególnie tych przewidzianych w programie Międzynarodowego Roku Książki (1972). Dokumentu nie podpisała delegacja rumuńska ${ }^{68}$.

${ }^{65}$ AAN, KCPZPR Wydział Kultury, LVI-954, Zalecenia narady przedstawicieli państwowych i społecznych kierownictw ruchu wydawniczego krajów socjalistycznych - Berlin 11 grudnia 1969, k nlb.

${ }^{66}$ Tamże.

67 AAN, KC PZPR Wydział Kultury, LVI-954, L. Karnkowski, Sprawozdanie $\mathrm{z}$ przebiegu narady kierownictw ruchu wydawniczego krajów socjalistycznych w Berlinie w dniach 9-13 XII 1969, k. nlb.

${ }^{68}$ RGANI, f. 5, op. 63, d. 97, Stykalin, przewodniczący Komitetu do spraw Druku przy Radzie Ministrów ZSRR, 13 XI 1971. 
Odnalezione inne materiały źródłowe, $\mathrm{w}$ tym przede wszystkim sprawozdania z kolejnych narad przedstawicieli wydawnictw literatury społeczno-politycznej oraz kierowników ruchu wydawniczego krajów socjalistycznych w Moskwie (23-28 listopada 1981 roku, 6-11 grudnia 1982 roku, 5-10 grudnia 1983 roku) oraz w Warszawie (4-7 grudnia 1984 roku) świadcza, że współpraca ta przynosiła być może efekty nie tak spektakularne, jak się spodziewano, ale widoczne.

Udało się stworzyć wspólne dla uczestników narad serie wydawnicze, w ramach których publikowano książki o podobnej tematyce lub wręcz te same, tłumaczone na języki państw - uczestników spotkań. Dokumenty odnalezione w zespole KC PZPR informuja, że w ramach serii „Krytyka burżuazyjnej ideologii i rewizjonizmu" (powstała w 1975 r.) w latach 1975-1982 wydano 14 książek. W latach 1977-1982 w innej serii, powstałej w 1976 r. pod nazwą, „Socjalizm: doświadczenia, problemy, perspektywy” (zmieniona potem na: „Realny socjalizm”) wydano 14 pozycji ${ }^{69}$. W serii „Maoizm - groźba dla ludzkości” do 1982 r. wydano w Polsce tylko jedną książkę (Andrzeja Halimarskiego Trzy kręgi polityki zagranicznej Chin, KiW 1982) ${ }^{70}$. W ramach czytelnikowskiej „Biblioteki zwycięstwa" ukazało się w Polsce w latach 1975-1982 ponad 30 dzieł literatury pięknej państw bloku wschodniego, w tym m.in. takie jak: Strofy o walce i braterstwie: antologia poezji (wiersze polskie i thumaczone z bułgarskiego, czeskiego, niemieckiego, rosyjskiego, słowackiego i węgierskiego), Reportaż spod szubienicy Juliusa Fučika, Siódmy krzyż Anny Seghers; W stronę zachodu stońca : opowieści i opowiadania o Wielkiej Wojnie Narodowej (przekład z rosyjskiego).

Ta współpraca przynosiła efekty również na innych polach. Na naradzie przedstawicieli wydawnictw encyklopedycznych, która odbyła się w Moskwie w grudniu 1977 roku dyrektor PWN, Stanisław Puchała

${ }^{69}$ Wśród tych książek znalazły się m.in. następujące: Ekonomiczne problemy rewolucji naukowo-technicznej w socjalizmie, tł. z rosyjskiego Anna Rosłan, Warszawa 1978; Ludmila P. Jewstigniejewa, Ksztaltowanie potrzeb w rozwiniętym społeczeństwie socjalistycznym, tł. z rosyjskiego Janina Skrzypkowa, Warszawa 1979; Płaca w ustroju socjalistycznym: zagadnienia teorii i praktyki, tł. z rosyjskiego A. Rosłan, Warszawa 1978; red. Stefan Angiełow, Socjalistyczny internacjonalizm: teoria i praktyka stosunków międzynarodowych nowego typu, t1. z rosyjskiego Tersa Bujnowska i in., Warszawa 1982; Socjalizm a dobrobyt społeczny, tł. z rosyjskiego Natalia Kuźmicz, Warszawa 1978; red. Paweł A. Ignatowski, Tadeusz M. Jaroszewski, Wyższość socjalizmu jako systemu społecznego, tł. z rosyjskiego: Roman Sroczyński, Henryk Widłaszewski, Stanislawa Wieczorek, Warszawa 1980; Michał Domagała, Kontrola zgodności prawa z konstytucja w europejskich państwach socjalistycznych, Warszawa 1986; Jacek Mazur, Planowanie tworzenia prawa w państwie socjalistycznym, Warszawa 1986.

70 AAN, KC PZPR Wydział Kultury LVI-958, Serie międzynarodowe (wydania w Polsce), k. nlb. 
informował o zawartości czterotomowej Encyklopedii PWN. Nieprzypadkowo wskazywał, jak dużą objętość zajmują w niej hasła dotyczące ZSRR, innych krajów socjalistycznych, współpracy i integracji socjalistycznej i marksizmu leninizmu. Tadeusz Kosmala, dyrektor i naczelny redaktor Wiedzy Powszechnej informował o wydaniu przez kierowaną przez niego oficynę wzmiankowanej już wcześniej Encyklopedii rewolucji październikowej na podstawie książki opublikowanej w ZSRR wydawnictwo „Sowietskaja Enciklopedia"71.

Mechanizm narad został rozciągnięty również na księgarzy. Na II Międzynarodowej Konferencji Księgarstwa Krajów Socjalistycznych, która obradowała w Lipsku w 1975 r. postanowiono, że w związku ze zbliżającą się konferencją Europejskich Partii Komunistycznych i Robotniczych w Berlinie oraz niedaleką 60 rocznicą rewolucji październikowej należy wytypować ,zestaw literatury do wspólnego propagowania w krajach socjalistycznych" 72 .

Próba opisu wysiłków podejmowanych przez władze PRL w celu upowszechnienia literatury społeczno-politycznej skłania do kilku podstawowych wniosków.

Po pierwsze z przeprowadzonej analizy wynika jasno, że wymaga ona wielorakich kompetencji. Niemożliwe jest zrozumienie tytułowej problematyki bez dobrej orientacji w historii politycznej PRL, stanowiącej niezbędny kontekst dla takich rozważań. Konieczne również wydaje się zgłębienie przynajmniej podstaw bibliologii politycznej w odniesieniu do analizowanego okresu. Trudno poruszać się w tej materii bez orientacji w historii historiografii i historii kultury.

Po drugie, materia, stanowiąca przedmiot analizy skłania do stawiania pytań, na które trudno uzyskać odpowiedzi dokonując kwerendy jedynie w krajowych zasobach archiwalnych i bibliotecznych. Tak jak w przypadku innych problemów historii Polski po II wojnie światowej, tak również i w wypadku literatury społeczno-politycznej zbadać należy tzw. sovietskij faktor. A to wymaga kwerendy w zbiorach archiwów moskiewskich.

${ }^{71}$ Matieriały sowieszczanija priedstawitielej knigoizdatielnych centrow i enciklopediczeskich izdatelstw socjalisticzeskich stran, Moskwa 1979, s. 32-42. Pierwsza narada wydawców encyklopedii w krajów socjalistycznych odbyła się w dniach 26-31 października 1965 r. w Moskwie. Zob. L. Marszałek, Narada encyklopedystów, „Przegląd Księgarski i Wydawniczy" 1966, nr 1.

${ }_{72}$ T. Hussak, II Międzynarodowa Konferencja Ksiegarstwa Krajów Socjalistycznych, „Przegląd Księgarski i Wydawniczy” 1975, nr 13-14. 
Po trzecie wreszcie losy książki społeczno-politycznej potwierdzają w sposób niezwykle wyrazisty, jak ważne jest dynamiczne ujmowanie nawet tak zdawałoby się „stabilnego" w sensie systemowym państwa, jakim była tzw. Polska Ludowa. PRL niejedno miał imię i traktowanie go jako jednoznacznej figury symbolicznej bardziej utrudnia niż ułatwia zrozumienie istoty tego państwa. Jeżeli tego przekonania nie przekujemy na praktykę interpretacyjną $w$ pracach naukowych trudno nam będzie wyjaśnić, jak się to stało, że -posługując się pewnym skrótem myślowym - funkcjonariusze partii i państwa od książek w 1952 kazali usuwać z bibliotek dzieła tow. Wiesława (Władysława Gomułki), a w 1984 ,dojrzewali" do propagowania Ferdydurke Witolda Gombrowicza.

\section{Streszczenie}

\section{Władza a książka społeczno-polityczna w PRL 1956-1989}

Tematem artykułu jest sposób traktowania przez powojenne władze komunistyczne w Polsce tzw. literatury społeczno-politycznej. Podstawą źródłową poczynionych ustaleń są przede wszystkim materiały archiwalne zgromadzone w zespole akt Komitetu Centralnego PZPR w Archiwum Akt Nowych i dokumenty odnalezione w moskiewskim Rosyjskim Archiwum Państwowym Historii Najnowszej oraz prasa specjalistyczna. Przedmiotem szczegółowych analiz są takie problemy jak: pojęcie literatury społeczno-politycznej; zabiegi propagandowe wokół książki społeczno-politycznej (ze szczególnym uwzględnieniem genezy i rozwoju Dni Książki Społeczno-Politycznej „Człowiek Świat Polityka w latach 1967-1989), charakterystyka partyjnego instrumentarium upowszechniania książki społeczno-politycznej (partyjne komisje, Rada do Spraw Książki Społeczno-Politycznej przy Sekretariacie KC PZPR); analiza kanonu literatury społeczno-politycznej (elementy trwałości i zmian); wpływ Kremla na wydawnictwa społeczno-polityczne w Polsce.

\section{Summary}

\section{The Communist Authorities and the „Social-Political Book" in Poland, 1956-1989}

The article deals with the way the Communist authorities in Poland approached the issue of the so called "social-political" literature. The analysis is chiefly based on the archival materials assembled in the Fond: Central Committee, Polish United Workers' Party, kept at the Central Archives of Modern Records in Warsaw, on the documents from the Russian State Archive of Contemporary Hi- 
story in Moscow, and on the professional press. The major aspects analysed are: the concept of "social-political" literature; propaganda measures undertaken by the Communist authorities to proliferate this type of reading (with special emphasis on the Festival of the Social-Political Book during the years 1967-1989); characteristics of instruments developed by the Communist party dedicated to disseminating the reading of "social-political" literature (party commissions, the Council for the Social-Political Book affiliated with the Central Committee of the Communist party); the canon of "social-political" literature, and its constant and changeable elements; influence of the Kremlin on "social-political" publications in Poland. 